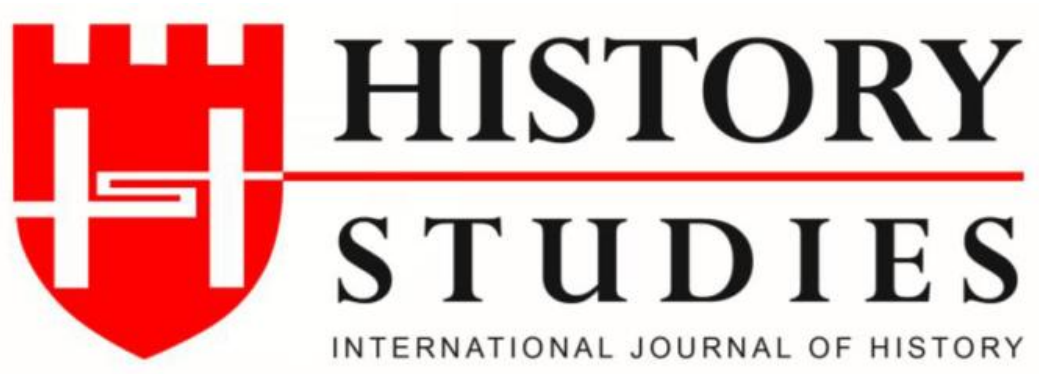

ISSN: 13094173 (Online) 1309 - 4688 (Print)

Volume 12 Issue 4, August 2020

DOI Number: 10.9737/hist.2020.887

Araştırma Makalesi

Makalenin Geliş Tarihi: 29.05.2020 Kabul Tarihi: 02.07.2020

Atıf Künyesi: Çiğdem Kılıçoğlu Cihangir, “Yunan Ulusçuluğunun Doğuşunda Sıradışı Bir Keşiş, Fizik

Teorisyeni ve Öğretmen: Lesvoslu Veniamin", History Studies, 12/4, Ağustos 2020, s. 1481-1503.

\title{
Yunan Ulusçuluğunun Doğuşunda Sıradışı Bir Keşiş, Fiżik Teorisyeni ve Öğretmen: Lesvoslu Veniamin
}

\author{
An Extraordinary Monk, A Theorist of Physics and A Teacher in the Process of Rising \\ of Greek Nationalism: Benjamin of Lesbos
}

\author{
Dr. Çiğdem Kılıçoğlu Cihangir \\ ORCID No: 0000-0002-8596-7215 \\ Ankara Üniversitesi
}

Volume 12

\begin{abstract}
Öz: Lesvoslu Veniamin, Batı literatüründe Çağdaş Yunan Aydınlanması olarak adlandırılan ve 18. yüzyılın ikinci yarısından 1821'deki Yunan ayaklanmasına kadar etkisini sürdüren Yunan kültür hareketinin önemli figürlerinden biridir. 1762-1824 y1lları arasında yaşayan Veniamin, Fransız Devrimi yıllarında eğitim gördüğü Paris'te Batı'nın aydınlanmacı ve ihtilalci fikirleriyle tanışmış, bu fikirleri beraberinde Osmanlı ülkesine taşıyarak Rum dünyasının kültürel, toplumsal ve siyasal dönüşümünde rol oynamıştır. Lesvos (Midilli) doğumlu olmakla birlikte, ismi en çok, hayatının önemli bir kısmını geçirdiği Ayvalık'la anılmıştır. Zira Osmanlı coğrafyasının, yüzünü Batı'ya çevirmiş ticaret merkezleri olarak bilinen Ayvalık ve İzmir'de, bir öğretmen olarak Rum eğitiminin geliştirilmesi için kayda değer çalışmalar yapmış ve bu nedenle Batı Anadolu Rumlarının kültürel gelişiminde ayrıcalıklı bir yere sahip olmuştur.
\end{abstract}

Mensubu olduğu Rum Ortodoks milletinin, o yıllardaki çoğu öğretmeni gibi aynı zamanda keşiş olan Veniamin'in, fizik ve doğa bilimleri alanında öne sürdüğü teorileri ve aydınlanmacı fikirleri, yalnızca Kilise'nin tepkisini çekmekle kalmamış, Rumların etnik kimliklerini kazanma serüveninde bir yol gösterici olarak Osmanlı Devleti'nin çöküşüne zemin hazırlayan Yunan ayaklanmasına kapı aralamıştır. Yunanistan devletinin kuruluş sürecinde geçici Yunan Meclisi'nde vekillik görevinde de bulunan Veniamin, Rumların/Yunanların ulusal uyanışı için üstlendiği misyondan dolayı, Yunan tarihyazımında "ulus öğretmeni" olarak nitelendirilmiştir.

Yunanca kaynaklara dayanarak hazırlanan bu çalışmada, Yunan ihtilalinin hazırlık aşaması olan eğitim ve aydınlanma seferberliği, bu sürecin perde arkasında yer alan Rum öğretmen Lesvoslu Veniamin'in yaşam hikâyesi ve ideolojisi üzerinden değerlendirilmeye çalışılmış; Rumlar arasında aydınlanmacı -ve ulusçu- fikirlerin yeşertilmesi ve yayılmasında Veniamin'in rolü tartışılmıştır.

Anahtar Kelimeler: Aydınlanma, Ayvalık Akademisi, Beniamin Lesbios, Filiki Eteria, Lesvoslu Veniamin, Pantahikiniton, Yunan Aydınlanması, Yunan İsyanı. 
Abstract: Benjamin of Lesbos is one of the remarkable figures of the Greek cultural movement which is named in western literature as the Modern Greek Enlightenment from the second half of the 18th century to the Greek revolt in 1821. Benjamin, who lived between the years of 1762-1824, met the ideas of enlightenment and revolution in Paris where he had studied during the Revolution years and by bringing along himself these ideas to the Ottoman lands played a role in cultural, social and political transformation of the Ottoman Greek community. As well as he was born in Lesbos, his name is mostly remembered with Ayvalık where he lived a significant part of his life. Because he carried out notable activities as a teacher in order to improve the Greek education in Ayvalik and İzmir which were known as the commerce centres of Ottoman lands that had commercial and cultural ties with the West. For this reason, he had a significant place in the cultural progress of the Greeks of Western Anatolia.

The ideas and theories about physics and natural sciences of Benjamin, who was also a monk, like most of the teachers of the Greek Orthodox community of which he was a member, not only attracted the reaction of the Patriarchate, but also opened a road to the Greek revolt which paved the way for the decline of the Ottoman Empire as a guide in the adventure of gaining ethnical identity of the Greeks. Benjamin, who also served as a deputy in the provisional Greek Assembly during the establishment of the Greek state, was described as "the teacher of the nation" in Greek historiography due to the mission he undertook for the national awakening of the Greeks.

In this study which was prepared based on Greek sources, the mobilization of education and enlightenment which consisted the preparation phase of the Greek revolution was tried to be analyzed through the life story and ideology of the Greek teacher Benjamin Lesbios, also the role of Benjamin in the cultivation of the enlightening and nationalist ideas among Greeks was discussed.

Keywords: Academy of Kydonies, Benjamin of Lesbos, Benjamin Lesbios, Enlightenment, Greek Enlightenment, Greek Revolt, Pantachekineton, Philike Hetaireia.

$$
A \gamma \varepsilon \omega \mu \dot{\tau} \tau \rho \eta \tau o \varsigma \mu \eta \delta \varepsilon i ́ \varsigma ~ \varepsilon \imath \sigma i ́ \tau \omega . . .1
$$

\section{Giriş}

Platon, Akadimos tepesinde kurduğu okulun, iki bin yıl sonra Helen diyarının batısında yeniden diriltileceğini öngörebilmiş midir? Ya da bilimsel düşüncenin, yüzyıllar, binyı1lar sonra yeni bir çağ başlatacağını? Aydınlanmanın yegâne yolunun "bilgiden" geçtiğini çağlar önce keşfeden filozof, Batı Avrupa'yı Ortaçağ karanlığından kurtaracak yeni tip düşünce sisteminin esin kaynaklarından biri olacağını bilebilir miydi?

Rönesans'tan Aydınlanma Çağı'na uzanan süreçte Batı Avrupa'da kurulan bilim akademileri, ${ }^{2}$ yalnızca Platon'un ünlü “Akadimia"sının adından esinlenmiyor, aynı zamanda antikiteyle bilimsel ve felsefi yönden bağ kurarak bilgiye ve bilime yeniden kutsiyet atfediyordu. 18. yüzyıla damgasını vuran Aydınlanma, bir bakıma Antik Yunan kültürünün ve

\footnotetext{
${ }^{1}$ Platon'un Akademisinin kapısında yazan ve “Geometri bilmeyen giremez.” anlamına gelen söz. Platon'a göre matematik, felsefenin zorunlu ön koşuluydu. Bu bağlamda değerlendirildiğinde, söz konusu ifade, felsefi düşüncenin temelini oluşturan bilgiyi ve bilimi yüceltiyordu. İbrahim Kelağa Ahmet, Yunanca-Türkçe Arkaik Sözler ve Eylemsiler Sözlüğü, İthaki Yay., İstanbul, 2016, s. 18.

${ }^{2}$ 16. yüzyıldan itibaren Avrupa'da kurulan bilim akademileri ile ilgili olarak bkz. Mustafa Yıldırım, "17. Yüzyılda Avrupa'da Kurulan Bilim Akademileri ve Bilimsel Gelişmelerdeki Rolleri”, ÇKÜ Sosyal Bilimler Enstitüsü Dergisi, Cilt: 10, Özel Say1, Aralık 2019, s. 96-113; Ayhan Hakan, "Dünyada ve Türkiye'de Akademilerin Tarihçesi ve Bugünkü Durumu”, Ankara Üniversitesi Eğitim Bilimleri Fakültesi Dergisi, C. 15, S. 2, 1982, s. 221-230.
} 
felsefesinin dirilişiydi. Aydınlanmanın yolu, mitler ve hurafelerin beslediği ancien régime’ $\mathrm{i}$-ve dogmaları- bilgiye ve akla dayanarak yıkmaktan geçerken, ${ }^{3}$ Antik Yunan, Batı Avrupa'nın kültürel referans noktalarından biri haline gelmişti.

Bir yandan Avrupa'da yükselen Yunan hayranlığı, diğer yandan Yunan tüccarlarının 18. yüzyılda Avrupa ile kurdukları güçlü ticari bağlar, Aydınlanma düşüncesinin Osmanlı-Yunan coğrafyasına -Osmanlı egemenliği altındaki Yunan anakarası ve Anadolu'nun batı kıyılarınataşınmasında etkili oldu. ${ }^{4}$ Ticaretle zenginleşen Yunan diasporası ile Osmanlı bürokrasisinde etkin bir konumda olan Fener Rumları, Aydınlanma hareketinin Yunan dünyasında benimsenmesi ve uygulanmasına dair farklı yönelimler sergilemiş olsalar da, Yunan eğitim ve kültürünün geliştirilmesi noktasında, başlangıçta aynı yolu izlediler, yeni okulların ve matbaaların kurulmasına destek oldular, Yunanca kitapların basılmasını teşvik ettiler; Yunan dünyasının bir nevi kültürel finans kaynakları oldular. ${ }^{5}$ Böylece 18. yüzyılın son çeyreğine gelindiğinde, Yunanlar arasında geniş çaplı bir düşünce hareketi ortaya çıktı. ${ }^{6}$

Çağdaş Yunan Aydınlanması olarak adlandırılan bu süreçte, çoğu Batı'da eğitim aldığı için Avrupa Aydınlanmasına bizzat tanıklık eden, insan, akıl, bilgi odaklı yeni tip düşünce sisteminden etkilenen ve bu düşünceleri Osmanlı idaresi altındaki Rumlara ${ }^{7}$ taşımak için seferber olan Yunan entelijansiyası, eğitimden politikaya uzanan çok geniş bir yelpazede faaliyet gösterdi. En önemli temsilcileri arasında Velestinli Rigas ve Adamantios Korais gibi isimlerin bulunduğu Yunan aydınlanma hareketi, özellikle 18. yüzyılın son çeyreğinden itibaren kurulan yeni okullar $^{8}$ ve bu okullarda öğretmenlik yapan aydınlanmacı öğretmenler vasıtasıyla genç kuşaklara aktarılmaya ve Rum/Yunan dünyasında yayılmaya başladı.

Aydınlanmacı fikirlerin kısa sürede Osmanlı Devleti'nin batı bölgelerinde yaşayan Rumlar arasında yayılması, bu bölgelerin coğrafi ve ticari olarak Avrupa etkisine daha açık olmasından kaynaklanmaktadır. Ancak bu gelişmeyi tek başına coğrafyanın etkisi ya da Rumların Avrupa ile ilișki kurmasının bir sonucu olarak değerlendirmek yetersizdir. Avrupa'nın Helenseverliğinin yanı sıra, belki bundan daha önemli bir etki olarak Osmanlı yönetiminin de bu gelişmede pay sahibi olduğunu belirtmek gerekir. Zira Osmanlı Devleti’nin kendine özgü toplumsal yapısı -millet sistemi- ve bu yapıdan kaynaklanan göreli özgürlük anlayışı -her milletin din, eğitim, sosyal vb. alanlarda kendine ait kurallar bütününe sahip ve tabi olmas1- da, bir anlamda, Rum dünyasında yeni okulların açılmasını ve yeni düşüncelerin yayılmasını kolaylaştırd1.

\footnotetext{
${ }^{3}$ Max Horkheimer - Theodor W. Adorno, Aydınlanmanın Diyalektiği, Felsefi Fragmanlar, (Çev. Nihat Ülner, Elif Öztarhan Karadoğan), Kabalcı Yayıncılık, İstanbul, 2014, s. 19; Ahmet Çiğdem, Aydınlanma Felsefesi, Ağaç Yayınc1lik, İstanbul, 1993, s. 11.

${ }^{4}$ Molly Greene, Osmanlı Devleti ve Rumlar 1453-1768, (Çev. Zeynep Rona), Kitap Yayınevi, İstanbul, 2018, s. 215; Gregory Jusdanis, Gecikmiş Modernlik ve Estetik Kültür: Milli Edebiyatın İcat Edilişi, (Çev. Tuncay Birkan), Metis Yay., İstanbul, 1998, s. 35-40; Nikos Svoronos, Çağdaş Helen Tarihine Bakış, (Çev. Panayot Abacı), Belge Yay., İstanbul, 1988, s. 27-28.

${ }^{5}$ Svoronos, a.g.e., s. 30-31; K. Th. Dimaras, Neoellinikos Diafotismos, 5. B., Ermis, Athina, 1989, s. 7-10, 27-30; Pashalis M. Kitromilidis, Neoellinikos Diafotismos: Oi Politikes kai Koinonikes İdees, Morfotiko İdryma Ethnikis Trapezis, Athina, 2009, s. 72-82.

${ }^{6}$ Herkül Millas, Yunan Ulusunun Doğuşu, 2. B., İletişim Yay., İstanbul, 1999, s. 46.

${ }^{7} \mathrm{Bu}$ çalışmada Yunan kavramı, bütün Yunan kökenlileri tanımlamak üzere daha kapsayıcı bir terim olarak tercih edilmiş, Rum ise yalnızca Osmanlı idaresi altındaki [Yunan kökenli] Ortodoksları nitelemek üzere kullanılmıştır.

${ }^{8}$ Yunan aydınlanmasının coğrafyası ve bu süreçte kurulan Yunan okulları için bkz. İbrahim Kelağa Ahmet, "Çağdaş Yunan Aydınlanma Hareketinin Coğrafyası, Ortaya Çıkış Süreci ve Eğitim Alanındaki Etkileri”, Batı Kültür ve Edebiyatlarında Aydınlanma, (Yay. Haz. Battal Arvasi, Çağrı Eroğlu, Ebru Balamir, İlhan Karasubaşı), Ankara Üniversitesi Yay., Ankara, 2014, s. 240-242, 246-249.
} 
Öyle ki; Osmanlı Devleti açısından ayrılıkçı nitelik taşıyan Rum faaliyetlerinin çoğu, Osmanlı yönetiminin pek karışmadı ̆̆ -ya da millet sisteminin yapısı gereği çoğunlukla ilgisiz kaldığı- din adamları tarafından hayata geçirildi. Bununla beraber ruhban sınıfının, eğitimi de elinde tuttuğunu ve o yıllarda öğretmenlerin çok büyük bir kısmının aynı zamanda din adamı olduğunu da belirtmek gerekir. Zira ruhban sınıfına mensup olmak, o dönemde hem kendi cemaatleri gözünde bir saygınlık göstergesiydi hem de bu sayede faaliyetlerini, ayrılıkçı olsun ya da olmasın, din perdesi altında kolaylıkla yürütebiliyorlard1. Bir nevi papaz cübbesi, Osmanlı yönetimine karşı koruyucu bir kalkan görevi görüyor, böylece şüphe çekmiyorlardı. ${ }^{9}$ Dolayısıyla aydınlanmacı fikirleri benimsemiş̧ "öğretmen din adamları" ya da "din adamı öğretmenler", Rum okullarında yeni düşüncelerin yayılmasını kolaylaştıran öğretim programlarını da kendileri ürettiler. ${ }^{10}$ Bu çalışmaya konu olan Lesvoslu Veniamin de bir din adamı ve aynı zamanda öğretmendi.

Bununla birlikte Kilise'nin genel eğilimi statükoyu ve kendi meşruiyetini korumaktan yana olduğu için aydınlanmacı fikirler kendisi için de tehdit oluşturuyordu. ${ }^{11}$ Zira her şeyden önce, Aydınlanmanın seküler bir temeli vardı ve bu akım, bir anlamda, ruhani gelenekte bir kopuşu temsil ediyordu. ${ }^{12}$ Özellikle Fransız Devrimi'nin ardından eşitlik, özgürlük, adalet ilkeleriyle bezenmiş yeni siyasal formların oluşmaya başlamasıyla Kilise'nin ayrıcalıklı statüsü sarsılıyor ve Ortodoksları din temelinde bir arada tutan sosyal yapı, yerini yeni bir dayanışma bağı olarak ulusa birakiyordu.

$\mathrm{Bu}$ çalışma, Aydınlanma düşüncesinin Yunan dünyasına yansımasını, Yunan ulusçuluğunun doğuşunu ve Yunanların Osmanlı Devleti'nden bağımsızlaşma sürecini, bir Osmanlı Rum'u ve Aydınlanma felsefesinin taşıyıcılarından biri olan Lesvoslu Veniamin'in hayatı üzerinden aktarmayı amaçlamaktadır.

\section{1- Lesvoslu Veniamin'in Doğduğu Ortam ve İlk Yılları}

Aydınlanma hareketi, bütün Yunan dünyasına aynı düzeyde ve eş zamanlı olarak sirayet etmedi. Rum seçkin kadrosu -Kilise ve Fener aristokrasisi- içinde, Aydınlanmaya karşı yoğun direnç gösteren tutucu güçler bir yana, Osmanlı Devleti'nin Balkan ve Anadolu kesimlerinde geniş bir coğrafyaya yayılmış bulunan Rum cemaati -özellikle Anadolu'nun iç kesimleri ve Karadeniz bölgesindeki Rumlar- çok büyük bir çoğunlukla bu gelişmelerden haberdar değildi. Mora'daki Rum ile Kapadokya'daki Rum aynı dili bile konuşmuyordu. ${ }^{13}$ Böyle bir kültürel parçalanmışlık içinde, Rigas'ın Anayasası ya da Korais'in Adelfiki Didaskalia'sı, ${ }^{14}$ Avrupa kültürü ile temas kurmuş, orada eğitim görmüş ya da bir yoldan aydınlanmacı fikirlerle tanışmış olan az sayıda Rum/Yunan entelektüeli tarafından, ancak belirli bölgelere ve sınırlı bir Rum Ortodoks nüfusa aktarılabilmiştir. Bu aktarım sırasında Rum ticaret burjuvazisini de göz

\footnotetext{
${ }^{9}$ Georgios Sakkaris, Ístoria ton Kydonion, Syllogos pros Diadosin Ofelimon Vivlion, Athinai, 1920 (Anatyposi 2005), s. 41.

${ }^{10}$ Greene, a.g.e., s. 221.

11 Victor Roudometof, Nationalism, Globalization and Orthodoxy: The Social Origins of Ethnic Conflict in the Balkans, Greenwood Press, Westport, Connecticut, 2001, s. 69.

12 Paskalis M. Kitromilides, “Aydınlanma ve Yunan Kültürel Geleneği”, Tarih Eğitimi ve Tarihte Öteki Sorunu, (2. Uluslararası Tarih Kongresi-Tebliğler), 2. B., Tarih Vakfı Yurt Yayınları, İstanbul, 2017, s. 31.

${ }^{13}$ Anadolu'nun iç kesimlerinde yaşayan Rum Ortodoks nüfus, ağırlıklı olarak Türkçe konuşmaktaydı. Paschalis M. Kitromilides, Alexis Alexandris, "Ethnic Survival, Nationalism and Forced Migration: The Historical Demography of the Greek Community of Asia Minor at the Close of the Ottoman Era", Deltio Kentrou Mikrasiatikon Spoudon, Tomos Pemptos, Athina, 1984, s. 14-15; Meryem Orakçı, "Karamanlıca Muhacir Sedası Gazetesine Göre Yunanistan'da Mübadelenin İlk Yılları ve Türkçe Konuşan Ortodoksların Yaşadığı Sorunlar”, Ankara Üniversitesi Türk Inkalap Tarihi Enstitüsü Atatürk Yolu Dergisi, Sayı: 65, Güz 2019, s. 267-269.

${ }^{14}$ Türkçesi Kardeşlik Öğretisi'dir. Korais'in bu risalesi ve Rigas'ın Anayasası için bkz. Millas, a.g.e., s. 102-109, 159-162.
} 
ardı etmemek gerekir. Zira Osmanlı egemenliği altındaki Yunan anakarası ve Batı Anadolu kıyılarındaki ticari merkezlerde, ticareti büyük oranda ellerinde tutan Rumlar, yalnızca Avrupa sermayesinin Osmanlı ülkesine girişine aracilık etmiyor, ${ }^{15}$ aynı zamanda Batılı fikirleri de Osmanlı Rum toplumuna ithal ediyorlardı. Bu bağlamda Rum ticaret burjuvazisi, kültürel sermayenin de bir nevi taşıyıcısı konumundaydı.

Venedik hâkimiyetindeki İon Adaları veya Osmanlı idaresi altında olmakla birlikte Fener Rumlarından seçilen voyvodaların yönettiği Eflak-Boğdan'daki gibi bir kültürel hareketlilik, Batı Anadolu kıyıları ile bazı Ege Adalarında ancak 18. yüzyıl sonları ile 19. yüzyıl başlarında görülmeye başladı. Aydınlanmacı fikirleri Batı Anadolu'ya taşıyan Rum entelektüellerinden biri olan Lesvoslu Veniamin'in, imparatorluğun batısında, Kuzey Ege'de, Edremit Körfezi'nin tam karşısında yer alan Lesvos'ta dünyaya gelmesi de, Batı etkisini daha çok hissetmesinde bir etken olarak düşünülebilir. Ancak Veniamin'in 1762 yılında ${ }^{16}$ hayatına başladığg bu Ege adası, coğrafi olarak Batı ile ilişki kurmaya müsait bir konumda yer alsa da, o dönemde henüz Aydınlanma düşüncesiyle tanışmamıştı ve Veniamin hayatının sonuna kadar bu adada yaşamış olsaydı, Yunan ihtilal hareketine -büyük olasılıkla- herhangi bir katkısı bulunmayacaktı. Daha açık bir ifadeyle, Lesvos ya da diğer adıyla Midilli Adası, Rumların Ege bölgesindeki diğer önemli kültürel merkezleri olan İzmir, Sakız ve Ayvalık kadar Aydınlanma hareketinden etkilenmemiş, ${ }^{17}$ hatta burası Kilise'nin temsil ettiği gelenekçi çevreyle sıkı bir bağ içinde olmuştu. $^{18}$

Lesvos'un Pilmar (Plomari) kazasında dünyaya gelen Veniamin'in erken dönem yaşamına dair pek fazla bilgi yoktur. Kimi kaynakta asıl isminin Vasilis olduğu ifade edilmektedir. ${ }^{19}$ Çiftçilikle geçimini sağlayan İoannis ve Amyrissa çiftinin beş çocuğundan biri ${ }^{20}$ olan Veniamin, okuma-yazmayı doğduğu kasabada öğrendi. ${ }^{21} 1776$ yılında Aynoroz (Agion Oros)'daki Pantokratoros Manastırı'nda eğitim görmeye başladı. Burada aldığı dini eğitimin ardından, aynı manastırın yetki alanındaki Ayvalık Agios Nikolaos Kilisesi'ne ${ }^{22} 1779$ yılında zangoç olarak atandı. Agios Nikolaos Kilisesi’nin başpapazı dayısıydı ve Veniamin,

${ }^{15}$ Orhan Kurmuş, Emperyalizmin Türkiye’ye Girişi, 2. B. Yordam Kitap, İstanbul, 2012, s. 77.

${ }^{16}$ G. A. Aristeidis, Veniamin o Lesvios, Itoi Vios Aftou, Typois Proodou, Athinisi, 1880, s. 22; İoannis N. Karamplias, İstoria ton Kydonion, Typografeion Ger. S. Hristou \& Yios, Athinai, 1949, s. 161. Kimi kaynakta Veniamin'in doğum tarihi 1759 olarak aktarılmaktadır. Bkz. Roksani D. Argyropoulou, O Veniamin Lesvios kai $i$ Evropaiki Skepsi tou Dekatou Ogdoou Aiona, Kentro Neoellinikon Erevnon Ethnikou İdrymatos Erevnon, Athina, 2003, s. 59.

${ }^{17}$ 19. yüzyılın başlarına kadar geleneksel eğitimin sürdürüldüğü İzmir, Sakız ve Ayvalık’ta, ticaretin gelişmesiyle bu bölgelerde etkin bir konuma yükselen Rum burjuvazisinin öncülüğ̈̈nde, aydınlanmacı eğilimleriyle öne çıkan okullar kuruldu. Kilise güdümündeki geleneksel eğitimin kaleleri olarak görülen bu bölgelerdeki değişim, aslında Yunan aydınlanmasının, eski tip eğitim sistemini değiştirerek yenilikçi düşüncelerin yayılmasını mümkün kılma hedefine bir anlamda ulaşıldığını göstermektedir. Kitromilidis, Neoellinikos Diafotismos, s. 77-78; Kelağa Ahmet, "Çağdaş Yunan Aydınlanma Hareketinin Coğrafyası...”, s. 250.

${ }^{18}$ Roksani D. Argyropoulou - Pashalis M. Kitromilidis, "O Diafotismos ston Horo tis Aiolidas", Mytilini kai Aivali (Kydonies), Mia Amfidromi Shesi sto Voreioanatoliko Aigaio, (Ed. P. M. Kitromilidis-P. Mihailaris), Institouto Neoellinikon Erevnon Ethnikou Idrymatos Erevnon, Athina, 2007, s. 61.

${ }^{19}$ Argyropoulou, O Veniamin Lesvios kai i Evropaiki Skepsi..., s. 59.

${ }^{20}$ Veniamin'in ikiz erkek kardeşleri ve iki de kız kardeşi vard. Argyropoulou, O Veniamin Lesvios kai i Evropaiki Skepsi..., s. 59.

${ }^{21}$ Aristeidis, a.g.e., s. 22.

${ }^{22}$ Günümüzde Ayvalık'taki Biberli Cami'dir. Ahmet Yorulmaz, Ayvalık'ı Gezerken, 4. B., Geylan Kitabevi, 1994, s. 114. Kilise'nin Aynoroz Pantokratoros Manastırı'na bağlı olmas1 ile ilgili olarak bkz. Dimitrios Stratis, "Sheseis Agiou Orous kai Kydonion", Mytilini kai Aivali (Kydonies), Mia Amfidromi Shesi sto Voreioanatoliko Aigaio, (Ed. P. M. Kitromilidis-P. Mihailaris), Institouto Neoellinikon Erevnon Ethnikou Idrymatos Erevnon, Athina, 2007, s. 52. 
Aynoroz'daki eğitiminin ardından keşiş olduğunda, bir Hristiyan geleneği olarak yapılan dini isim alma ritüelini, dayısının da ismi olan Veniamin'i alarak yerine getirmişti. ${ }^{23}$

Ayvalık'ta bulunduğu zaman zarfında Veniamin, Ayvalık'ın ileri gelenlerinden Papaz Oikonomos'un ${ }^{24} 1780$ yllında inşa ettirdiği Panagia ton Orfanon Okulu'ndaki dersleri takip etti. Bu okulda Veniamin'in eğitimiyle özel olarak ilgilenen Oikonomos, bir y1l kadar sonra onu, eğitimine devam etmesi için Patmos ve Sakız'daki daha yüksek seviyedeki okullara ${ }^{25}$ yönlendirdi. Önce Patmos'taki Patmiada Ruhban Okulu'nda öğrenim gören Veniamin, daha sonra Sakız Okulu'na devam etti ve öğrenimini başarıyla tamamlayarak 1789 yılında Ayvalık'a geri döndü. Kısa bir süre Oikonomos'un kurduğu okulda öğretmenlik yaptıktan sonra, Ayvalık Rum cemaatinin sağladığı burslarla üniversite öğrenimi görmek üzere 1790 yılında Batı Avrupa'ya doğru yola koyuldu. ${ }^{26}$

Veniamin'in yaşam çizgisinin Avrupa'ya ve doğa bilimleri alanına yönelmesinde, adalardaki öğrenimi sırasında tanıştığı, ilerleyen süreçte Filadelfia (1805-1813) ve Edirne (1813-1821) Metropolitliklerini ${ }^{27}$ üstlenecek olan Dorotheos Proios'un ${ }^{28}$ önemli bir yeri olduğu öne sürülmektedir. ${ }^{29} 1786$ yılı civarında ve -büyük olasılıkla- Sakız Adası'nda tanışan iki genç, ortak ilgi alanları neticesinde sıkı bir dostluk geliştirdi. Yaşıt olmalarına rağmen -Veniamin'in eğitim hayatına daha geç yaşlarda başladığı da hesaba katılırsa- Proios ${ }^{30}$ Veniamin'den dört yıl kadar önce matematik ve doğa bilimleri alanında eğitim almak üzere Batı Avrupa'ya gitti. Ardından Veniamin, yakın arkadaşı Proios'un izinden giderek 1790 yılında önce Pisa, daha sonra Paris'te üniversiteye devam etti. ${ }^{31}$

Her ikisinin de bir süre eş zamanlı olarak Paris'te bulunması ve burada Adamantios Korais'in temsil ettiği aydınlanmacı çevreyle temasta olması, büyük olasılıkla bu şehirde de bir süre görüştüklerini akıllara getirmekle birlikte, asıl önemli nokta, iki arkadaşın Fransız Aydınlanmasını yakından izleyerek yeni fikirlerle tanışmış olmasıydı. Bu fikirlerin etkisi altında Proios, ruhban sınıfındaki tutucu güçlerin yoğun baskısına rağmen, Rum kültür dünyasında yenilikçi faaliyetlere önderlik edecek ve aydınlanmacı kimliğiyle tanınan az sayıda din adamından biri olarak Kilise'de metropolitlik seviyesine kadar yükselecekti. Hatta Veniamin, Avrupa'daki eğitimini tamamlayıp yurda döndükten sonra, görüşlerinden dolayı Kilise ile ters düşünce, kendisine destek olanlardan birisi de Dorotheos Proios olacakt1. ${ }^{32}$

\footnotetext{
${ }^{23}$ Argyropoulou, O Veniamin Lesvios kai i Evropaiki Skepsi..., s. 59.

${ }^{24}$ Papaz Oikonomos'un asıl ismi İoannis Dimitrakellis'tir. Oikonomos adı, aslında kilisedeki görevini gösteren unvanıdır, zaman içinde soyadı yerine geçmiştir. Sakkaris, a.g.e., s. 17; Karamplias, a.g.e., s. 80.

${ }^{25} \mathrm{Bu}$ okullar ve ilerleyen süreçte kurulan benzerleri, genellikle orta öğretim seviyesinde eğitim veren kurumlardı, ancak zaman zaman bazı okullarda yüksekokul seviyesinde dersler de okutuluyordu. Patrikhane Akademisi, Kuruçeşme Rum Okulu (Üniversitesi), Bükreş ve Yaş Akademileri, Ayvalık Akademisi vb. bunlardan bazılarıydı. Kelağa Ahmet, "Çağdaş Yunan Aydınlanma Hareketinin Coğrafyası...", s. 247-248.

${ }^{26}$ Aristeidis, a.g.e., s. 22-24; Argyropoulou, O Veniamin Lesvios kai i Evropaiki Skepsi..., s. 60-61.

${ }^{27}$ Demetrius Kiminas, The Ecumenical Patriarchate: A History of Its Metropolitanates with Annotated Hierarch Catalogs, The Borgo Press, USA, 2009, s. 53, 90.

28 Dorotheos Proios, 1821'deki Yunan ihtilali neticesinde Osmanlı idaresi tarafindan idamla cezalandırılan metropolitlerden biridir.

${ }^{29}$ Roksani D. Argyropoulou, O Veniamin Lesvios: Oramatistis kai Themeliotis tis Eleftherias ton Ellinon, Mikri Vivliothiki Didaskalon tou Genous, Athina, 2019, s. 35-36; Argyropoulou, O Veniamin Lesvios kai $i$ Evropaiki Skepsi..., s. 60-61.

30 Dorotheos Proios'un bu dönemde Sakız Okulu'nda öğretmenlik yaptı̆̆ı ve yaşıtı Veniamin'in de öğretmeni olduğu iddia edilmektedir. Sakkaris, a.g.e., s. 42.

${ }_{31}^{31}$ Argyropoulou, O Veniamin Lesvios: Oramatistis..., s. 37; Sakkaris, a.g.e., s. 42.

${ }^{32}$ Giorgos Valetas, Veniamika: Ta Mikra Keimena tou Veniamin Lesviou kai oi Viografikes Piges tou, Ekdoseis Etaireias Aiolikon Meleton, Mytilini, 1982, s. 333.
} 
Veniamin, devrim yıllarında bulunduğu Paris'te, École Polytechnique’te öğrenim gördü, matematik, doğa bilimleri, felsefe ve astronomi üzerine çalışmalar yaptı. ${ }^{33}$ Hümanizmin, akılcılığın ve bilimsel bilginin yanında, sekülerizmin merkeze oturtulduğu Fransız Aydınlanmasının etkisinde kald. Fransız ansiklopedistlerin yanı sıra, dersler aldığı düşünürlerin çalışmaları, Veniamin'in inanç dünyasını ve dünyaya bakışını yeniden şekillendirdi. ${ }^{34}$ Veniamin, Paris’teki gözlemleri ve çalışmaları neticesinde edindiği birikimi, Ayvalık'a 1798 yılında geri döndüğ̈̈nde, ${ }^{35}$ eğitim yoluyla Osmanlı Rumlarına aktarmaya başladı.

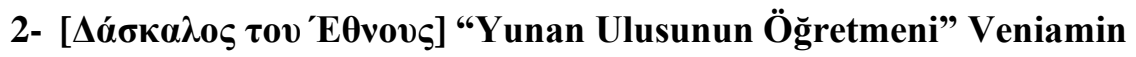

Batı Avrupa'daki eğitimini Ayvalık Rum cemaatinin burslarıyla tamamlayan Lesvoslu Veniamin, Ayvalıklılara duyduğu minneti, bu kentte öğretmenlik yaparak gösterecekti. Bu dönemde Avrupa'ya yerel cemaatler tarafından az sayıda öğrenci gönderildiği için, bu öğrenciler, geleceğin öğretmenleri olarak Rumların kültürel gelişimi bağlamında önem arz ediyordu. Bu nedenle Veniamin, Avrupa'daki eğitimini tamamladığında, Doğu Ege'nin Rumlar açısından önemli iki kültürel merkezi de, Veniamin'in bilgilerinden yararlanmak istedi. Birisi, Veniamin'in ikinci memleketi olarak addedilen Ayvalık, ${ }^{36}$ diğeri ise eğitim hayatının önemli bir kısmını geçirdiği Sakız Adası'ydı. Veniamin, Papaz Oikonomos'un ve Ayvalık Rum cemaatinin desteğiyle okuduğu için Ayvalık'1 tercih edecekti. Bu tercihte, vefa borcunun ve minnet duygusunun yanı sıra, o yıllarda Sakız Okulu'nun müdürü olan ve aydınlanma karşıtı görüşleriyle bilinen Athanasios Parios ile çalışmak istememesi etkili olmuştu. Ayrıca Sakız Okulu'ndan, 1796 senesinde Parios ile anlaşamadığı için ayrılan arkadaşı Dorotheos Proios'un yerine getirilmek istenmesi de, Veniamin'in Ayvalık'ta kalması için yeterli bir sebepti. ${ }^{37}$

Veniamin'in Avrupa'daki eğitimi sırasında, Papaz Oikonomos hayatını kaybetmişti, ancak

Volume 12

Issue 4

August

2020 onun, Ayvalık'ta yüksek dereceli bir okul kurma hayali Ayvalık Rum cemaati tarafindan üstlenilmişti. ${ }^{38}$ Veniamin, 1798 yılında Ayvalık'a döndüğünde, önce, kendisinin de kısa bir dönem eğitim aldığı, Oikonomos'un Panagia ton Orfanon Okulu'nda öğretmenlik yapmaya başladı. Ardından, Rum cemaatinin, arsasından inşasına kadar bütün masraflarını büyük bir özveriyle karşıladığı, binası 1803 yılında tamamlanan ve daha yüksek dereceli bir eğitim kurumu olduğu için Akademi adı verilen yeni okula transfer oldu. ${ }^{39}$ Yenilikçi eğitim anlayışı ve aydınlanmacı öğretmenleriyle kısa sürede yıldızı parlayan Ayvalık Akademisi, dönemin en nitelikli Rum eğitim kurumlarından biri haline geldi. ${ }^{40}$ Osmanlı coğrafyasının çeşitli bölgelerinden Rum gençlerinin yanı sıra, Yunan kökenli olmayan Balkan topluluklarından ve hatta Amerika'dan bile öğrenci alan okul, ${ }^{41}$ aydınlanmacı görüşlerin yayıldığ

\footnotetext{
${ }^{33}$ Aristeidis, a.g.e., s. 24; Argyropoulou, O Veniamin Lesvios kai i Evropaiki Skepsi..., s. 63.

${ }^{34}$ Dimaras, Neoellinikos Diafotismos, s. 98, 128; Kitromilidis, Neoellinikos Diafotismos, s. 465.

${ }^{35}$ Ayvalık'a dönmeden kısa bir süre önce Veniamin, dönemin ünlü astronomu William Herschel'in ürettiği büyük teleskopu görmek ve astronomi ile ilgili çalışmalar yapmak üzere İngiltere’ye de gitmiştir. Aristeidis, a.g.e., s. 24.

${ }^{36}$ Aristeidis, a.g.e., s. 6.

${ }^{37}$ Argyropoulou, O Veniamin Lesvios kai i Evropaiki Skepsi..., s. 65.

${ }^{38}$ Karamplias, a.g.e., s. 127-133; Sakkaris, a.g.e., s. 35-37.

${ }^{39}$ Sakkaris, a.g.e., s. 39; Nikos D. Sotirakis, Veniamin Lesvios - Viografia, Mytilini, 1939, s. 9-10.

40 Ayvalık Akademisi hakkında geniş bilgi için bkz. Giorgos Valetas, "Istoria tis Akadimias ton Kydonion", Mikrasiatika Hronika, Tomos 4, 1948, s. 145-208; Karamplias, a.g.e., s. 112-207; Sakkaris, a.g.e., s. 34-84; Richard Clogg, "Two Accounts of the Academy of Ayvalık (Kydonies) in 1818-1819", I Kath'imas Anatoli: Studies in Ottoman Greek History, The Isis Press, İstanbul, 2004, s. 135-169.

${ }^{41}$ Abdolonyme Ubicini, Letters on Turkey: An Account of the Religious, Political, Social and Commercial Condition of the Ottoman Empire, Part II, The Raiahs, including the Greeks, Armenians, Latins, Israelites, London, 1856, s. 82.
} 
konumuna gelerek yalnızca Rum dünyasında değil, Balkan coğrafyasındaki diğer topluluklar açısından da fikirsel bir dönüşümün kapısını araladı.

Grigorios Sarafis ${ }^{42}$ ile birlikte Ayvalık Akademisi'nin idaresini üstlenen Veniamin, burada felsefe (metafizik ve etik), matematik (aritmetik, geometri, trigonometri ve cebir) ve doğa bilimleri (meteoroloji, astronomi ve fizik) dersleri verdi. ${ }^{43}$ Geleneksel çizgiyi reddeden yaklaşımıyla Veniamin'in öğretileri, Yunan dünyasının kültürel değişimine ve gelişimine öncülük ederken, onun öğretmenliği sırasında Akademi, altın çağını yaşadı. Özellikle fizik alanında uyguladığı deneysel metotlar ve aydınlanmacı düşünürlerin etkisinde geliştirdiği teoriler, Rumlar arasında yeni bir bilinçlenmeye yol açacak düzeydeydi. Bilimsel ve seküler bilginin yayılması, var olan düzenin de sorgulanmaya başlaması anlamına geldiği için, Veniamin'in görüssleri ve okulda uyguladığı metotlar, en çok Kilise'yi rahatsız etti. Bu nedenle Veniamin, henüz öğretmenliğinin ilk yıllarından itibaren Kilise'nin tepkisini çekti ve gelenekçi (tutucu) güçlerin hedefi haline geldi.

1803 yılında aydınlanmacı ögretilerinden dolayı Veniamin, ruhban sınıfı içinde Kollyvades Hareketi $^{44}$ olarak bilinen tutucu bir çevreye mensup iki papaz ${ }^{45}$ tarafından dini kozmolojiyi reddettiği ve ateist olduğu gerekçesiyle Kilise'ye (Rum Ortodoks Patrikhanesi) şikâyet edildi. Aslında Veniamin'le bir süredir çatışma halinde olan, Kollyvades Hareketi'nin öncülerinden, Sakız Okulu müdürü Athanasios Parios'un kışkırtmaları neticesinde böyle bir gelişmenin yaşanmış olması muhtemeldir. Zira Parios'un aydınlanma karşıtllı̆ğ, uzunca bir süre Veniamin'in şahsında somutlaşacak ve bu tutucu hareketin etkisi altında Parios, gerek Kilise içinde gerekse dışında Veniamin'e karşı bir tepki oluşturmayı başaracaktı. ${ }^{46}$ Bununla birlikte Veniamin, kendisini destekleyen az sayıda yüksek rütbeli din adamı -ki aralarında eski arkadaşı Dorotheos Proios ${ }^{47}$ da bulunuyordu- ile Fener aristokrasisine mensup bazı ailelerin yardımıyla bu sıkıntılı süreci atlattı. Patrikhane'deki sorgusunun ardından Ayvalık Akademisi'ndeki görevine iade edilen Veniamin, burada 1812 y1lına kadar ders vermeyi sürdürdü. ${ }^{48} \mathrm{Ne}$ var ki, kendisine karşı açılan savaşa, Ayvalık Rum cemaat heyeti içindeki hizipleşme neticesinde Parios'un tarafını tutan gelenekçilerin de eklenmesiyle 1812 yılında okuldan ayrılmak zorunda kaldı. ${ }^{49}$ Yerine, yine Ayvalıklıların burslarıyla Avrupa'da eğitim gören ve Veniamin'e göre daha uzlaşmacı bir tutum sergileyen Theofilos Kairis atand $1 .{ }^{50}$

Veniamin'in Ayvalık Akademisi'nden ayrılması, bu okulda öğrenim gören ve Veniamin'in öğretilerine tutkuyla bağlı olan öğrencileri de üzüntüye sevk etti. Öğrencilerin bir kısm1 Veniamin'in peşi sıra okuldan ayrılırken, bir kısmı da bundan sonraki süreçte Akademi'ye

\footnotetext{
${ }^{42}$ Grigorios Sarafis hakkında bilgi için bkz. Karamplias, a.g.e., s. 156-160; Sakkaris, a.g.e., s. 35-36.

${ }^{43}$ Aristeidis, a.g.e., s. 26; Sotirakis, a.g.e., s. 10.

${ }^{44}$ Adını, Doğu Ortodoks Kilisesi'nde cenaze ve anma törenlerinde dağıtılan "koliva" isimli haşlanmış buğdaydan alan bu hareket, 18. yüzyılın ikinci yarısından itibaren Aynoroz'daki keşişler arasında ortaya çıkmış, Hristiyanlıktaki geleneksel ritüellerin ve uygulamaların savunuculuğunu yapmış ve her türlü yenileşmeyi dinden sapma olarak görmüştür. Konuyla ilgili detaylı bilgi için bkz. Georgios D. Metallinos, "İ Dynamiki tou Diafotismou sti Drasi tou Kollyvadon", O Eranistis, 21, 1997, s. 189-200.

${ }^{45}$ Birisi Samuil Andrios, diğeri ise Ignatios Thiraios'tur. Sotirakis, a.g.e., s. 13.

${ }^{46}$ Athanasios Parios ile Lesvoslu Veniamin arasındaki çatışma için bkz. Argyropoulou, O Veniamin Lesvios kai $i$ Evropaiki Skepsi..., s. 71-75.

${ }^{47}$ Dorotheos Proios'un bu kriz sürecinde ve sonrasında Lesvoslu Veniamin ile temas kurduğunu ve ona destek olduğunu söylemek mümkündür. İki arkadaşın mektuplaşmaları için bkz. Ellinikos Filologikos Syllogos Konstantinoupoleos, Syngramma Periodikon, Tomos 12: 1877-78, Typois Voutyra kai Sas, en Konstantinoupolei, 1879, s. 214-230; Aristeidis, a.g.e., s. 101-103.

${ }^{48}$ Sakkaris, a.g.e., s. 38, 51; Karamplias, a.g.e., s. 140

${ }^{49}$ Sotirakis, a.g.e., s. 10-14.

${ }^{50}$ Theofilos Kairis hakkında detaylı bilgi için bkz. Kostas P. Mandilas, O Theofilos Kairis kai o Neoellinikos Diafotismos, Ekdoseis Anoihti Poli, Athina, 2002.
} 
damgasını vuracak olan Veniamin yanlıları-Kairis yanlıları çekişmesinde başrolü oynayacakt ${ }^{51}{ }^{51}$ Ancak her ne olursa olsun, Lesvoslu Veniamin'in Ayvalık'ta biraktığ 1 miras öyle benimsendi ki, 1821'de Ayvalık Akademisi y1k1ld1ktan sonra yerine kurulan ve Akademi'nin ardı11 olarak nitelendirilen Ayvalık Rum Lisesi (Gymnasio), kuruluş yıldönümlerinde düzenlediği müsamerelerde ve yayımladığı bildirilerde, Akademi'nin kuruluşunda ve işleyiş̧inde büyük katkısı olan Veniamin'den övgüyle bahsetti, onu "Yunan ulusunun ögretmeni ${ }^{, 52}$ olarak and ${ }^{53}$

Ayvalık Akademisi'nden ayrıldıktan sonra, aynı yıl (1812) Veniamin, İstanbul'a, Patrikhane Akademisi'ne müdür olarak davet edildi. ${ }^{54}$ Aslında bu ilginç bir gelişmedir, zira Kilise, Veniamin'in görüşlerinden hoşlanmıyor, faaliyetlerine şüpheyle yaklaşıyordu. Zaten Veniamin de Kilise içindeki tutucu güçler tarafından kendisine yöneltilen düşmanlığın bu sirada yeniden alevlenmesiyle kendisine teklif edilen görevi icra edemeyecek, İstanbul'dan ayrılarak doğduğu Lesvos Adası'na gidecekti.

Lesvos'tayken Veniamin'in, Ayvalık yakınlarında bir köyde öğretmenlik yapan yeğeni Ioannis Psomellis ile yaptığı yazışmalardan, Ayvalık'tan ayrıldığı için duyduğu üzüntüyü ve Lesvos'ta eski öğrencileriyle birlikte yeni bir okul kurma çabalarını okumak mümkündür. ${ }^{55}$ Ancak bu dönemde, dini kurumlarla s1k1 bağlara sahip olan Lesvos'ta geleneksel eğitimin ağırlığı hissediliyordu. ${ }^{56} \mathrm{Bu}$ yüzden ada, yeni düşünceleri kolay kolay kabul etmedi ve Veniamin'in buradaki okul kurma girişimleri de sonuçsuz kaldı.

Böylece yeniden -aynı yıl içinde ikinci kez- İstanbul'a dönen Veniamin, bu defa 1817 yılına kadar Osmanlı başkentinde kaldı ve Fener Rum camiasına, özel öğretmen olarak dersler verdi. Ders verdiği kişiler arasında, henüz o yıllarda çocuk yaşta bulunan, Yunan romantik edebiyatının en önemli temsilcilerinden Aleksandros ve Panagiotis Soutsos kardeşler gibi isimler yer almaktaydı. Ayrıca Eflak-Boğdan Beyliklerinde uzun yıllar voyvodalık yapan ünlü Mavrokordatos ailesinin bir üyesi olan Aleksandros Mavrokordatos -Yunanistan devleti kurulduktan sonra Yunan başbakanı- da, aynı ideolojik yaklaşımdan ötürü Veniamin ile yakın ilişki kuran kişiler arasındayd1. ${ }^{57}$ Nitekim Mavrokordatos ile bağlantısı, Veniamin'in İstanbul'dan sonra, Eflak Beylik Akademisi olarak da addedilen Bükreş Akademisi'ne müdür olarak atanmasinda rol oynayacaktı.

Müdürlük teklifini Veniamin'e yapan Eflak voyvodası Ioannis Karatzas, ${ }^{58}$ Aleksandros Mavrokordatos'un anne tarafından akrabasıydı. O yıllarda büyük bir çalkantı içinde olan Bükreş Akademisi'nin yeniden organize edilmesi için iyi bir öğretmene duyulan ihtiyaç, Mavrokordatos'un Veniamin'i önermesiyle giderildi ve Veniamin, İstanbul'da geçirdiği süre içinde çeşitli Yunan okullarından aldığı öğretmenlik ve müdürlük davetlerini reddetmesine

\footnotetext{
${ }^{51}$ Karamplias, a.g.e., s. 141; Sakkaris, a.g.e., s. 52.

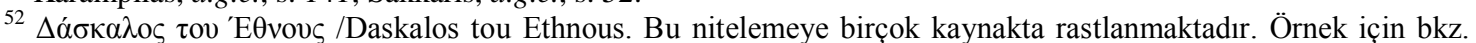
Sotirakis, a.g.e., s. 59; Argyropoulou, O Veniamin Lesvios: Oramatistis..., s. 8-9, 17; Aristeidis, a.g.e., s. 21.

531876 yılında Ayvalık Gymnasio'sunun kuruluş yıldönümünde yayımlanan bir şiirde, Ayvalık Akademisi'nden ve Veniamin'den övgüyle bahsedilmiştir. Şiirin tamamı için bkz. Aristeidis, a.g.e., s. 115-125.

${ }_{54}^{54}$ Argyropoulou, O Veniamin Lesvios: Oramatistis..., s. 56.

${ }^{55}$ Söz konusu mektuplara Aristeidis'in kitabında yer verilmiştir. Aristeidis, a.g.e., s. 103-105. Konuyla ilgili olarak ayrica bkz. Sotirakis, a.g.e., s. 15-17.

${ }^{56}$ Argyropoulou - Kitromilidis, a.g.m., s. 60.

${ }^{57}$ Argyropoulou, O Veniamin Lesvios: Oramatistis..., s. 59; Argyropoulou, O Veniamin Lesvios kai i Evropaiki Skepsi..., s. 86.

${ }^{58}$ Ioannis Karatzas hakkında bilgi için bkz. Dimitris Skarlatos Soutzos, Ellines İgemones Vlahias kai Moldavias, Athina, 1972, s. 209-219.
} 
karşın, ${ }^{59}$ Eflak’tan gelen teklife olumlu yanıt verdi. ${ }^{60}$ Böylece 1817 y1lında İstanbul'dan ayrılarak Bükreş'e giden Veniamin, gelenekçi-yenilikçi bölünmesinden kaynaklanan ideolojik ayrılıkların $^{61}$ hat safhada olduğu yeni okulunda, kendi öğretilerini yayabilmek için bir firsat elde etti. Aynı süreçte Bükreş Akademisi'nin idare heyetine dâhil olan Mavrokordatos da, Veniamin'in okul müdürlüğünü üstlenmesinin, Akademi' de yeni bir dönemi başlattığına işaret ediyordu. $^{62}$

17. yüzyılda kurulan ve Yunan dünyasının en köklü yüksek eğitim kurumlarından biri olan Bükreş Akademisi, ${ }^{63}$ Veniamin döneminde gelişme gösterdi, okulda Batı akademileri örnek alınarak yeniden bir düzenleme yapıldı, yeni öğretmenler işe alındı, yaklaşık 400 kişiyi bulan bir öğrenci sayısına ulaşıld1. ${ }^{64} \mathrm{Ne}$ var ki, bu durum çok uzun sürmedi. Veniamin'in göreve başlamasından sekiz ay kadar sonra, 1818 y1lının Ekim ayında, Ioannis Karatzas'ın, Yunan bağımsızlı̆g 1 için çalışan ve isyan hazırlığı içinde olan Filiki Eteria ${ }^{65}$ ile bağlantısı ve yerli Rumen ileri gelenleriyle yaşadığ Cezalandırılma korkusuyla henüz görev süresini tamamlamadan Eflak'tan ayrılan Karatzas ve beraberindeki Mavrokordatos, böylece, Akademi'ye binbir umutla getirdikleri Veniamin'i de yalnız bırakıyorlardı. Nitekim düzen bozulunca, Veniamin'in Akademi'deki koltuğu da sarsılmaya başladı.

Veniamin'in eğitimde Yunan ulusçuluğunu öne çıkaran yaklaşımları, özellikle Rumenleri rahatsız etmişti. Her ne kadar Rumenler genel olarak Yunan eğitimindeki gelişmelerin ve Yunan ulusal uyanışının kendi toplumlarının bilinçlenmesinde önemli bir rol oynadığını kabul etseler de ${ }^{66}$ Eflak'taki durum biraz farklıydı. Rumenlerin yaşadığ 1 huzursuzluğun ana kaynağı, Fenerli Rum yöneticilerin özellikle vergi hususunda adaletsiz davranmalarıydı. Yerel güçler arasındaki bu çatışma, ${ }^{67}$ bizzat voyvodanın kontrolünde olan Akademi'ye de yansıyordu. Zira okulun öğretmenlerinden, ideolojik tutumuna kadar her ayrıntı voyvoda tarafindan belirleniyordu. Dolayısıyla voyvodaya karşı hissedilen bütün duygular, okulda da yank1 buluyordu. Üstelik buna bir de Veniamin'in çağına göre -özellikle dini açıdan- sınırları zorlayan görüşleri eklenince, yalnızca Rumenler değil, gelenekçi eğitim yanlısı olan ve Karatzas, Eflak'1 terk ettikten sonra okulun eski haline dönmesi için uğraş veren tutucu çevre de Veniamin'in Akademi'de kalmasını istemedi. Daha açık bir ifadeyle bu dönemde Eflak'ta

\footnotetext{
59 1816'da Odessa'daki Yunan Ticaret Okulu'ndan öğretmenlik teklifi alan Veniamin, bu daveti reddederken, Atina'da Filomousos Cemiyeti tarafindan kurulan okulun teklifini olumlu karşıladı. Ancak koşulların uygun olmamas1 neticesinde bu okula da gitmedi. Argyropoulou, O Veniamin Lesvios kai i Evropaiki Skepsi..., s. 87.

${ }^{60}$ Sotirakis, a.g.e., s. 18-19.

${ }^{61} \mathrm{Bu}$ bölünmenin nedenleri ve tarafların görüşleri için bkz. Sotirakis, a.g.e., s. 18-20. Argyropoulou, $O$ Veniamin Lesvios: Oramatistis..., s. 60-62.

${ }^{62}$ Sotirakis, a.g.e., s. 20.

${ }^{63}$ John Edwin Sandys, A History of Classical Scholarship: The Eighteenth Century in Germany and the Nineteenth Century in Europe and the United States of America, Vol. 3, Cambridge University Press, 2010, s. 359; Tryfon E. Evangelidis, I Paideia epi Tourkokratias (Ellinika Sholeia apo tis Aloseos mehri Kapodistriou), Tomos Defteros, A. P. Halkiopoulou, en Athinais, 1936, s. 388.

${ }^{64}$ Aristeidis, a.g.e., s. 30.

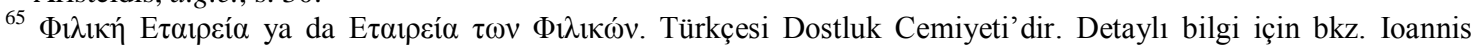
Filimon, Dokimion Istorikon peri tis Filikis Etaireias, ek tis Typografias Th. Kontaksi kai N. Loulaki, en Nafplia, 1834.

${ }^{66}$ Argyropoulou, O Veniamin Lesvios kai i Evropaiki Skepsi..., s. 93. Balkan topluluklarının Yunan ulusal uyanışından etkilenmeleriyle ilgili olarak ayrıca bkz. Roudometof, a.g.e., s. 68-69.

${ }^{67}$ Rumenler ve Fenerli Rum yöneticiler arasındaki çatışma noktaları için bkz. Barbara Jelavich, Balkan Tarihi 18. ve 19. Yüzyıllar, (Çev. İhsan Durdu, Gülçin Tunalı, Haşim Koç), Küre Yayınları, İstanbul, 2006, s. 112-124, 232-233.
} 
yaşanan siyasal, ekonomik ve toplumsal çatışma, Veniamin'e de yansıdı. Bu durum, Veniamin'in görüşlerinin burada da kolay kabul görmediğini gösteriyordu. ${ }^{68}$

Bükreş’ten ayrılmaya zorlanmasının ardından Veniamin, 1818 yılı sonlarında Boğdan Beylik Akademisi'ne, nam-1 diğer Yaşs Akademisi'ne geçiş yaptı. Bu sırada Boğdan voyvodası olan Skarlatos Kallimahis ${ }^{69}$ de tıpkı Eflak voyvodası Karatzas gibi Akademi'deki ders içeriklerini ve işleyişi değiştirip okulu daha ileri bir seviyeye taşımak istiyordu. ${ }^{70}$ Aydınlanmacı fikirlere açık olması dolayısıyla Veniamin'e kucak açan Kallimahis'in, Yunan eğitiminin geliştirilmesine yönelik düşünceleri ve eylemleri yalnızca Yaş Akademisi ile sınırlı değildi, Osmanlı coğrafyasında çeşitli bölgelerdeki Rum okullarının desteklenmesi için bağışlarda da bulunuyordu.

Ancak bu yıllarda aydınlanmacı fikirler, Osmanlı Devleti'nin bütünlüğü açısından tehlikeli eylemlere dönüşmeye başlamıştı. Özellikle Tuna Beylikleri (Eflak-Boğdan), bu dönemde oldukça güç kazanmış olan Yunan ihtilal örgütü Filiki Eteria'nın stratejik birer üssü haline gelmişti. $^{71}$ Öyle ki, Veniamin bile Boğdan'dayken Filiki Eteria'ya üye olmuş, Yaş Akademisi'nde öğretmenlik yaptığı süre içinde, esasen, bu ihtilal örgütünün faaliyetleriyle meşgul olmuştu. ${ }^{72}$ Hatta örgütün, Mora'da bir okul kurma girişiminin bizzat içinde yer alarak okul nizamnamesini bile hazırlayan Veniamin'in, kurulacak okula müdür olarak atanması gündeme gelmişti. Ancak bu girişim bazı engellemeler neticesinde sonuçsuz kalacaktı. ${ }^{73}$ Yine Yaş'ta bulunduğu sırada, o dönemde İngiliz hâkimiyetinde olan İon Adalarında -Korfu'dahenüz kuruluş çalışmaları devam eden Ion Akademisi'nden kendisine yapılan öğretmenlik teklifini de, Filiki Eteria'nın ihtilalci faaliyetlerine katılmak ve örgüte destek sağlamak için geri çevirdi. ${ }^{74}$ Bunun yerine, Anadolu Rumları arasında, özellikle zengin Rum burjuvazisi içinden kendisine önemli miktarda taraftar bulan Filiki Eteria'nın ${ }^{75}$ Anadolu'daki merkezlerinden biri sayılan İzmir'e gitmeyi seçti. Böylece Tuna Beyliklerinde geçirdiği yaklaşık üç yılın ardından, 1820 y1lında, Anadolu topraklarına bir kez daha dönen Veniamin, Mart 1821'de Mora'da Yunan ayaklanması patlak verene kadar İzmir'deki Evangeliki Okulu'nda müdür olarak görev yapt1.

İzmir Rumlarının en köklü eğitim kurumu olan Evangeliki Okulu, ${ }^{76}$ aslında geleneksel eğitim anlayışının hâkim olduğu bir okul ${ }^{77}$ olmasına rağmen, Veniamin'e ev sahipliği yaptığı dönemde okulun bu çizgiden saptığ 1 ve ulusçu ideolojinin ön plana çıkmaya başladığı görülmektedir. Zaten Veniamin'in bu okuldaki görevi kabul etmesinin ardında yatan asıl nedenin, Filiki Eteria'nın faaliyetlerinin bir parçası olarak cemiyete üye kazandırmak ve Yunan ulusal uyanışını sağlamak olduğu iddia edilmektedir. ${ }^{78}$ Ancak bu siyasi misyonunu Veniamin,

\footnotetext{
${ }^{68}$ Argyropoulou, O Veniamin Lesvios kai i Evropaiki Skepsi..., s. 92-95.

${ }^{69}$ İsmi Türkçe kaynaklarda İskerlet voyvoda olarak geçen Skarlatos Kallimahis, 1819 yılında Ruslarla işbirliği yaptığı gerekçesiyle görevden alınarak İstanbul'a getirtilmiş, 1821'de Yunan isyanı neticesinde ailesiyle birlikte Bolu'ya sürgün edilmiştir. Mübahat S. Kütükoğlu, "Yunan İsyanı Sırasında Anadolu ve Adalar Rumlarının Tutumları ve Sonuçları”, Üçüncü Askeri Tarih Semineri: Tarih Boyunca Türk-Yunan İlişkileri (20 Temmuz 1974'e Kadar), Genelkurmay ATASE Yay., Ankara, 1986, s. 145.

${ }^{70}$ Argyropoulou, O Veniamin Lesvios kai i Evropaiki Skepsi..., s. 98.

${ }^{71}$ Filiki Eteria'nın Eflak-Boğdan'daki faaliyetleri ve isyan süreci ile ilgili olarak bkz. Jelavich, a.g.e., s. 229-239.

${ }^{72}$ Aristeidis, a.g.e., s. 31; Sotirakis, a.g.e., s. 21.

${ }^{73}$ Filimon, ...peri tis Filikis Etaireias, s. 242-243; Aristeidis, a.g.e., s. 31-32.

${ }^{74}$ Argyropoulou, O Veniamin Lesvios kai i Evropaiki Skepsi..., s. 99-101.

${ }^{75}$ Filiki Eteria'ya üye olan Anadolu Rumları için bkz. Maria N. Vaianni, Mikrasiatikos Ellinismos kai Filekpaideftiki Etaireia 1836-1900, Ekdoseis Enoseos Smyrnaion, Athina, 2003, s. 95-105.

${ }^{76}$ Evangeliki Okulu ile ilgili geniş bilgi için bkz. Hristos Sokratis Solomonidis, I Paideia sti Smyrni, Athina, 1962, s. 18-200.

${ }^{77}$ Kitromilidis, Neoellinikos Diafotismos, s. 448.

${ }^{78}$ Solomonidis, a.g.e., s. 79; Sotirakis, a.g.e., s. 21.
} 
asli görevi olan öğretmenlikle birlikte yürütüyordu. Başka bir deyişle, Veniamin'in amacına ulaşma noktasında sarıldı ̆̆ 1 ilk ve en önemli silahı eğitimdi.

Evangeliki Okulu'nda yeğeni Psomellis ile birlikte çalışan ve ondan destek alan Veniamin, ${ }^{79}$ Ayvalık Akademisi'nde uyguladığı allilodidaktiki (karşılıklı öğretim) ${ }^{80}$ metodunu İzmir'e de taşıyarak bu sistemin Rum okulları arasında yaygınlaşmasına öncülük etti. ${ }^{81}$ Ancak Veniamin burada henüz bir y1l bile kalmadan, Mart 1821'de Mora'da Yunan ayaklanmas1 patlak verdi. Ardından Sinod Meclisi'nin aldığı hızlı bir kararla Patrikhane, modern eğitim veren bütün Rum okullarının kapatılmasına ve felsefe dersleri veren öğretmenlerin işten çıkarılmasına hükmederek Veniamin gibi ihtilalci fikirleri olan öğretmenleri hedef gösterdi. ${ }^{82} \mathrm{Bu}$ gelişme Evangeliki Okulu'nun kapanmasına yol açarken ${ }^{83}$ Veniamin de öğretmenlik hayatını bu okulda noktaladı ve İzmir'den ayrıldı.

\section{3- Lesvoslu Veniamin'in Siyasi Profili}

Lesvoslu Veniamin'in Batı'da aldığı eğitim sırasında tanıştığı Aydınlanma felsefesi, onun hayata bakışının ve ideolojisinin temelini teşkil ediyordu. Bir öğretmen olarak Veniamin, aydınlanmacı düşüncelerini dersleri aracılığıyla zaten geniş bir kitleyle paylaşıyordu, ancak bu fikirleri siyasal düzlemde eyleme geçirmesi, Yaş’ta bulunduğu sirada (1818-1820) Filiki Eteria'ya üye olmasıyla başladı.

1814 yılında Yunan ticaretinin önemli merkezlerinden biri olan Odessa'da Emmanuil Ksanthos, Athanasios Tsakalof ve Nikolaos Skoufas adında üç Yunan tüccar tarafindan kurulan Filiki Eteria, ${ }^{84}$ Osmanlı Devleti'ne karşı Rum/Yunanları ayaklandırarak bağımsız bir Yunan devleti kurmayı amaç edinmişti. Başlangıçta zengin Yunanlardan yeterli desteği bulamadığı için zayıf ilerleyen bir örgüt olmasına rağmen, birkaç yıl içinde merkezini İstanbul'a taşıyarak ve Osmanlı coğrafyasının çeşitli merkezlerinde gizli şubeler açarak üye sayısında hızlı bir artış sağlamıştı. ${ }^{85}$ Filiki Eteria'nın ilerleme kaydettiği bu dönemde, önce Bükreş, ardından Yaş’ta bulunan Veniamin'in cemiyete üye olması için ortam ve koşullar oldukça uygundu. Zira stratejik konumu dolayısıyla Tuna Beyliklerinin Filiki Eteria için ayrı bir önemi vardı ve cemiyet -çoğunlukla voyvodalardan da destek alarak- neredeyse bütün bölgeye hızla yayılmıştı.

Veniamin, Yaş'ta bulunduğu sırada, 1819 yılında Filiki Eteria'nın kurucularından Nikolaos Skoufas aracilığıyla bu örgüte üye oldu ${ }^{86}$ ve çok kısa bir süre içinde örgütün faaliyetlerinde aktif olarak görev aldı. Cemiyetin önemli isimlerinden, Boğdan voyvodasının (Skarlatos Kallimahis) kâtipliğini yapan Theodoros Negris'in evinde gizli toplantılara katılan Veniamin, cemiyetin eğitim ile ilgili faaliyetlerinin de bizzat içinde yer aldı ${ }^{87}$ Filiki Eteria'nın ihtilalci

\footnotetext{
${ }^{79}$ Solomonidis, a.g.e., s. 79-80.

80 Allilodidaktiki metodu ya da Lancaster sistemi, kısaca, üst sınıflardaki öğrencilerin daha alt sınıflardaki öğrencilere ders vermesi yöntemi olarak tanımlanabilir.

${ }^{81}$ Argyropoulou, O Veniamin Lesvios kai i Evropaiki Skepsi..., s. 101.

${ }^{82}$ Aynı yer.

${ }^{83}$ Evangelidis, a.g.e., (Tomos 2), s. 249; Ayşe Aksu, "Skolastik Eğitimden Helenizme Geçişte Bir Azınlık Okulu: İzmir Evangelike Rum Mektebi”, Kutadgubilig Felsefe-Bilim Araştırmaları, Haziran 2016, Sayı 30, s. 985.

${ }^{84}$ Jelavich, a.g.e., s. 229. Yunan tarihçi Filimon, Filiki Eteria'yı detaylı bir şekilde ele aldığı eserinde, cemiyetin kurucuları arasında başka birkaç isim daha zikretmekle birlikte, Emmanuil Ksanthos'un bu oluşuma sonradan katıldığını aktarmaktadır. Filimon, ...peri tis Filikis Etaireias, s. 132, 193.

${ }^{85} 1821$ 'deki Yunan ayaklanmasına kadar Filiki Eteria'ya üye olanların isim listesi için bkz. Valerios G. Meksas, $O i$ Filikoi: Katalogos ton Melon tis Filikis Etaireias ek tou Arheiou Sekeri, Athinai, 1937, s. 1-80; Ioannis Filimon, Dokimion Istorikon peri tis Ellinikis Epanastaseos, Tomos Protos, Typois P. Soutsa kai A. Ktena, Athinai, 1859, s. 387-416.

${ }^{86}$ Filimon, ...peri tis Ellinikis Epanastaseos, (Tom. 1), s. 400.

${ }^{87}$ Aristeidis, a.g.e., s. 31; Filimon, ...peri tis Filikis Etaireias, s. 242-243.
} 
fikirlerinin taşıyıcısı (apostol) olarak İzmir'de Evangeliki Okulu'nda öğretmenlik yaptığ sırada, cemiyete üye kazandırdığı ve cemiyet için bağış topladığı da, yeğeni Psomellis ile yaptığı yazışmalardan anlaşılmaktadır. ${ }^{88}$

Filiki Eteria'nın isyan hazırlığı, Mart 1821'de Mora'da bir silahlı ayaklanmayla neticelendi. Mora isyanı, Yunan Aydınlanması olarak adlandırılan düşünsel hareketin, artık eylemsel bir kimliğe büründüğünü, diğer bir ifadeyle ihtilal aşamasına gelindiğini gösteriyordu. $\mathrm{Bu}$ sırada Evangeliki Okulu'nda görev yapmakta olan Veniamin, okulun kapanması gündeme gelince, Nisan ayının başlarında İzmir'den ayrılarak Anadolu Rumlarından Yunan ayaklanmasına destek sağlamak üzere Ayvalık'a geçti. Ayvalıklıları isyana hazırladı ve Ayvalık'tan Mora'ya gemiyle cephane sevk edilmesine yardım etti. ${ }^{89}$

Veniamin'in Ayvalık'ta bulunduğu bir-iki aylık süre zarfinda, Rum ahalinin neredeyse tümüyle isyana katılması, Osmanlı yönetimini sert tedbirler almaya yöneltti, zira bu bölgedeki isyan engellenemediği takdirde bütün Batı Anadolu'ya yayılacak büyük çaplı bir hadiseye dönüşebilirdi. ${ }^{90}$ Haziran ayında Ayvalık'taki çatışmaların şiddetlenmesi üzerine Veniamin, bölge Rumlarının Ege adalarına kaçmasına yardım etti. ${ }^{91}$ Kendisi de, önce Ayvalık Akademisi'nin kütüphanesini -çatışmadan- kurtarmaya çalıştı, ardından İpsara, İdra ve Spetses Adaları üzerinden Ağustos ayında Mora yarımadasına geçti. ${ }^{92}$

Mora'da Aleksandros Mavrokordatos ile yeniden karşılaşan Veniamin, bundan sonra izlenecek yol ile ilgili Mavrokordatos'la fikir alışverişinde bulundu. Yunan ihtilalini -ya da isyanını- yürüten kadro arasında ortaya çıkan fikir ayrılı̆̆ında, ihtilalin zamana yayılması ve yoğun bir ön hazırlığın ardından gerçekleştirilmesi gerektiğini düşünen Mavrokordatos'a daha yakın bir tutum sergiledi. Bu sırada, Mora'nın kuzeyinde yer alan Fokida bölgesinin Amfissa kentinde Doğu Yunanistan Meclisi ${ }^{93}$ adı altında bir ihtilal meclisinin toplanması için Eylül 1821 'de yayımlanan bildirgeye imza koyanlar arasinda yer ald. ${ }^{94}$ Kasım 1821 'de Orta Yunanistan ( $\Sigma \tau \varepsilon \rho \varepsilon \alpha ́$ E $\lambda \lambda \alpha \dot{\alpha} \delta \alpha)$, Teselya ve Makedonya bölgelerinden temsilcilerin kat1lımıla toplanan bu meclis, Yunanistan'ın tamamını temsil etmediği için yerel nitelikte kaldı ancak Aralık ayında toplanacak olan ulusal nitelikteki ilk Yunan meclisi için de bir adım oluşturdu.

Osmanlı Devleti'ne karşı çıkarılan ayaklanmada, Yunan denetimi altına alınan bölgelerin idaresinin sağlanması amacıyla Aralık 1821'de Mora yarımadasında bulunan Epidavros'ta Yunan Millet Meclisi ${ }^{95}$ adıyla ilk Yunan ulusal meclisi oluşturuldu. Doğu Yunanistan, Batı Yunanistan, Adalar, Mora ve diğer bölgelerden temsilcilerin katılımıyla toplanan birinci mecliste, Lesvoslu Veniamin, Mora (Yerel) Senatosu'nun ${ }^{96} 20$ vekilinden biri olarak yer ald. ${ }^{97}$ Aynı mecliste Aleksandros Mavrokordatos da İcra Heyeti Başkanlığı yaptı. ${ }^{98}$

\footnotetext{
${ }^{88}$ Bu yazışmayı aktaran Argyropoulou, O Veniamin Lesvios kai i Evropaiki Skepsi..., s. 102.

${ }^{89}$ Ayn1 yer.

${ }^{90}$ Kütükoğlu, a.g.m., s. 140-141.

${ }^{91}$ Ioannis Filimon, Dokimion Istorikon peri tis Ellinikis Epanastaseos, Tomos Tritos, Typois P. Soutsa kai A. Ktena, Athinai, 1860, s. 360.

${ }_{92}$ Aristeidis, a.g.e., s. 33.

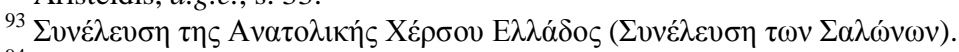

${ }^{94}$ Argyropoulou, O Veniamin Lesvios: Oramatistis..., s. 69.

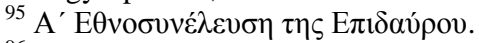

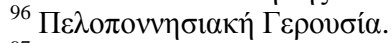

${ }^{97}$ Arheia tis Ellinikis Palingenesias (1821-1832): Ai Ethnikai Synelevseis, Tomos 3, Ekdosis Vivliothikis tis Voulis ton Ellinon, Athinai, 1971, s. 46.

${ }^{98}$ Arheia tis Ellinikis Palingenesias mehri tis Engatastaseos tis Vasileias, Tomos 1, ek tou Typografeiou D. A. Mavrommati, en Athinais, 1857, (Epanekdosis ipo tis Vivliothikis tis Voulis, Athinai, 1971), s. 32-33.
} 
Birinci Meclis'in en önemli faaliyeti, 1 Ocak 1822'de Yunanistan Geçici Yönetimi ${ }^{99}$ adıyla bir anayasa çıkararak Yunanistan'ın bağımsızlığını duyurmak oldu. ${ }^{100}$ Hemen ardından faaliyetlerini hızlandıran mecliste, Lesvoslu Veniamin de Ege Adaları Komiserliğine atand1. ${ }^{101}$ Görevi, Ege Adalarını ayaklanmaya hazır hale getirmek ve Yunan donanmasının ihtiyaçlarını karşılamak için adalar halkından vergi toplamak olarak belirlenmişti. ${ }^{102} \mathrm{Bu}$ görevi yerine getirmek için Temmuz ayının sonlarında Nafplio'dan ayrılarak Tinos, Paros, Naksos, Samos'un da aralarında olduğu birçok adayı ziyaret eden Veniamin, gittiği her yerde Yunan ihtilalinin amacını ve tasarılarını anlattı, ancak bazı adalarda ihtilalci düşüncelere dini açıdan karşı çıkan ${ }^{103}$ ve olan-bitenin mantığını kavrayamayan kesimlerle karşılaştığı gibi ihtilale yardım ettikleri takdirde abluka altına alınmaktan korkan ada sakinlerine de denk geldi. ${ }^{104}$ Aslında bu durum, Yunanların topyekûn isyana kalkışmadıklarını, Ege adaları da dâhil olmak üzere, özellikle Anadolu'da yaşayan Rumların -Ayvalık gibi Yunan aydınlanmasının ve ulusçuluğunun yoğun olarak hissedildiği Batı Anadolu'nun bazı bölgeleri hariç tutulursabüyük çoğunlukla gelişmelerin dışında olduğunu ve isyanın ağırlıklı olarak Yunan anakarasının belli başlı bölgeleriyle sınırlı kaldığını göstermektedir.

Nisan 1823'te, Mora yarımadasında bulunan Kynouria kentinin merkezi konumundaki Astros kasabasında toplanan Ikkinci Yunan Millet Meclisi, ${ }^{105}$ Veniamin'in görev aldığ 1 son Yunan meclisi oldu. Açıldıktan hemen sonra, hızla yasama faaliyetlerine girişen mecliste, Veniamin, geçici bir ceza kanunu hazırlanması için oluşturulan dokuz kişilik komisyona üye olarak seçildi. ${ }^{106}$ Böylece Yunan devletinin ilk ceza kanunu olan Apanthisma ton Engklimatikon, ${ }^{107}$ Veniamin'in de katkılarıyla hazırlandı ve 1 Temmuz 1824 'te yürürlüğe girdi. ${ }^{108}$

Veniamin'in bu meclisteki bir diğer faaliyeti de, dâhil olduğu bir okul projesiydi. Nisan 1824'te Yunanistan genelinde bilimin yaygınlaştırılması ve toplumun bilinçlendirilmesi amacıyla Mora yarımadasındaki Argos'ta Protypon Didaktirion ${ }^{109}$ adında bir yüksek okul kurma projesini hayata geçirmek için oluşturulan komisyonda yer ald1 ${ }^{110}$ Ancak 1821 'den beri Yunan ihtilalcileri arasında baş gösteren ve gittikçe şiddetini arttıran hizipleşmeden dolayı

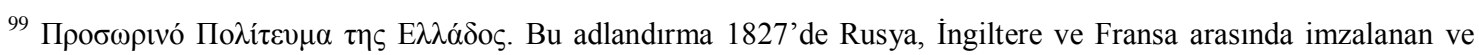
Yunanistan'ın üç büyük devlet tarafından tanınmasının ilk adımı olarak kabul edilen Londra Antlaşması'na kadar

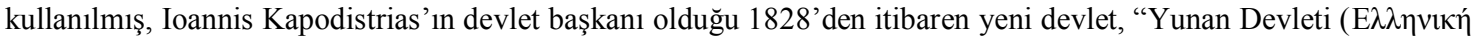

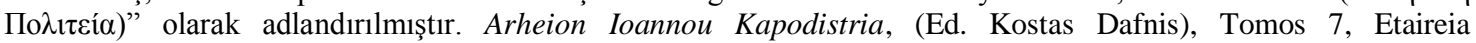
Kerkyraikon Spoudon, Kerkyra, 1986, s. 292; Richard Clogg, Modern Yunanistan Tarihi, (Çev. Dilek Şendil), İletişim, İstanbul, 1997, s. 58-60.

${ }^{100}$ Arheia tis Ellinikis Palingenesias..., Tomos 3, s. 25. Anayasa metninin tamamı için bkz. a.g.e., s. 21-35.

${ }^{101}$ A.g.e., Tomos 1, s. 400, 407-408; G. Aristeidis-Pappis, Sympliroma eis tin kata to Etos 1880 Ekdotheisan ip'aftou Viografian Veniamin tou Lesviou, Typois Proodou, en Athinais, 1889, s. 4-5.

${ }^{102}$ Arheia tis Ellinikis Palingenesias..., Tomos 1, s. 408; Argyropoulou, O Veniamin Lesvios: Oramatistis..., s. 72.

103 Ortodoks Yunanlar içindeki tutucu bazı çevrelerin ihtilal karşıtlıklarına benzer şekilde, Ege adalarının bir kısmında yoğun olarak ikamet eden -Yunan ya da başka uyruktan- Katolikler de bu süreci genel olarak olumsuz karşılamışlardır. Argyropoulou, O Veniamin Lesvios kai i Evropaiki Skepsi ..., s. 111.

${ }^{104}$ Aristeidis-Pappis, a.g.e., s. 5-6.

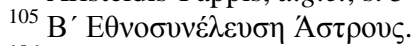

${ }^{106}$ Arheia tis Ellinikis Palingenesias..., Tomos 3, s. 77.

${ }^{107}$ Suçlar Derlemesi şeklinde Türkçeye çevrilebilir.

${ }^{108}$ Kodiks ton Nomon, Fylladion A': Apanthisma ton Engklimatikon tis B' Ethniki Synelevseos ton Ellinon, ek tis en İdra Typografias, 1824, s. 8'de kanunun yürürlüğe girdiği tarih bilgisi yer almaktadır. Kanunun tamamı için bkz. aynı eser.

109 Örnek/Model Okul olarak Türkçeye çevrilebilir.

${ }^{110}$ Arheia tis Ellinikis Palingenesias mehri tis Engatastaseos tis Vasileias, Tomos 2, Typois Dionysiou Koromila, en Athinais, 1862, (Epanekdosis ipo tis Vivliothikis tis Voulis ton Ellinon, Athinai, 1972), s. 360; Evangelidis, a.g.e., (Tomos 1), s. 248.
} 
proje, uygulama safhasına geçemedi. Veniamin ise ilerleyen süreçte Yunan siyasetinde ciddi kırılmalara yol açacak olan bu hizipleşmeye ${ }^{111}$ fazlaca tanık olamadan, 12 Eylül 1824'te, Nafplio'da tifüsten hayatını kaybetti. ${ }^{112}$

\section{4- Lesvoslu Veniamin'in İdeolojisi ve Eserleri}

Osmanlı coğrafyasında Rumların eğitim ve kültür faaliyetleri Kilise'nin sorumluluğu ve denetimi altında işliyordu. 17. yüzyıla kadar Rum milletinin okullaşma oranı düşük düzeyde seyrederken, yalnızca az sayıda Rum, Avrupa'da -özellikle İtalya'da- aldığı eğitimin ardından Osmanlı Devleti'nde iyi kademelerde çalışma imkânına sahip oluyordu. Saray hekimliğinin yanı sıra önemli pozisyonlarda çalışan bu entelektüel Rum sınıfı, çoğunlukla Aristotelesçi eğitimin merkezi konumunda olan Padova Üniversitesi'nde eğitim görüyor, edindikleri bilgi ve donanımı Osmanlı Devleti'ne -ve dolayısıyla kendi milletlerine de- aktarıyordu. ${ }^{113} 17$. yüzyılın sonlarından itibaren Avrupa'daki gelişmelerin de bir sonucu olarak Osmanlı Rum eğitim dünyasında bir canlanma dönemine girildi. Bir yandan Osmanlı coğrafyasında diğer taraftan Yunan ticaret kolonilerinin yoğun olarak yaşadığı Avrupa'nın önemli merkezlerinde çeşitli Rum/Yunan okulları kurulurken, Aydınlanma olgusunun da gelişmesine paralel olarak Aristotelesçi eğitimden deneysel bilime doğru bir yönelim başladı. ${ }^{114} \mathrm{Bu}$ yönelimin popüler hale gelmesiyle eğitim alanında benimsenen yeni yaklaşımlar, Kilise'nin yıllardan beri savunduğu Aristotelesçi eğilimin ister istemez karşısında yer alıyordu. Zira deneysel bilim, Kilise'nin kozmolojik teorisinin de sorgulanmasına yol açacak düzeyde ilerliyor, inançlı kesimin dünya ve evren algısını değiştirmeye başlıyordu. Diğer bir ifadeyle deneysel bilimin yaygınlaşması, felsefenin ilahiyata bağımlılı̆g 1 sona erdiriyor, evrenin metafiziksel boyutu yerine fiziksel yanını ön plana çıkarıyordu. ${ }^{115}$

O halde, Kilise'nin bu yeni tarz düşünce sistemine karşı olmasının temelinde, inananların

Volume 12

Issue 4

August

2020 evren algısının değişmesiyle kendi merkezi konumunun sarsılacağı inancı yatmaktaydı ${ }^{116} \mathrm{Bu}$ nedenle Kilise, Yunan Aydınlanması olarak addedilen dönemde, Batı'nın aydınlanmacı fikirlerinden etkilenen ve bu fikirleri Osmanlı Rum toplumuna aşılamaya çalışan, aralarında Lesvoslu Veniamin'in de bulunduğu Rum aydınlarının büyük bir kısmına şüpheyle yaklaştı. Yunan Aydınlanmasının en titiz temsilcilerinden biri olan Lesvoslu Veniamin'in, Kilise'yle çatıştığı en temel nokta da, doğa kanunlarını ilahiyat çerçevesinden çıkarıp felsefeyle açıklaması oldu. ${ }^{117}$ Bilimin dogmalardan arındırılması gerektiğini savunan Veniamin'in benimsediği fikirlerin kaynağı Batı Aydınlanmasıydı. Fransız İhtilali'nin etkisi altındaki yıllarda eğitim gördüğü Paris'te Veniamin, Condillac'ın çalışmalarından etkilenmiş, ayrıca Lagrange'ın matematik, Lavosier'nin kimya konusundaki öğretileri, bilimsel ve ideolojik tutumunun şekillenmesinde önemli esin kaynakları olmuştu. ${ }^{118}$ Veniamin'in bilim ve felsefeye dair genel görüşü, tıpkı Platon gibi, matematiğin, bilimin temeli ve felsefi düşüncenin de çıkış noktası olduğu yönündeydi. ${ }^{119}$ Pedagojik yaklaşımının çerçevesini ise Locke'un bu konudaki teorileri oluşturmaktaydı. ${ }^{120}$ Veniamin'e göre insan ruhunda üç önemli güç vardı: Hafıza, akıl ve tasavvur (hayal gücü). Bunların ancak kültür ve eğitim yoluyla geliştirilebileceğini savunan

\footnotetext{
${ }^{111}$ Clogg, Modern Yunanistan Tarihi, s. 53-56.

${ }_{112}$ Argyropoulou, O Veniamin Lesvios: Oramatistis..., s. 75.

${ }^{113}$ Greene, a.g.e., s. 215; Kitromilidis, Neoellinikos Diafotismos, s. 29.

${ }^{114}$ Kelağa Ahmet, "Çağdaş Yunan Aydınlanma Hareketinin Coğrafyası...”, s. 246-248; Greene, a.g.e., s. 218.

${ }^{115}$ Greene, a.g.e., s. 218-219.

${ }^{116}$ Roudometof, a.g.e., s. 72.

${ }^{117}$ Dimaras, Neoellinikos Diafotismos, s. 98; K. Th. Dimaras, Ellinikos Romantismos, Ermis, Athina, 2009, s. 248.

${ }^{118}$ Argyropoulou, O Veniamin Lesvios kai i Evropaiki Skepsi..., s. 63.

${ }^{119}$ Sotirakis, a.g.e., s. 27.

${ }^{120}$ Argyropoulou, O Veniamin Lesvios kai i Evropaiki Skepsi..., s. 215.
} 
Veniamin, çeşitli bilim dallarını kategorize ederek bir sistematik ortaya koymuştu. Buna göre, dil, tarih, coğrafya ve mitoloji çalışmak hafızayı güçlendiriyor; mantık, aritmetik, geometri, cebir, trigonometri, mekanik, astronomi, fizik, kimya ve etik, aklı besliyor ve geliştiriyor; müzik, resim, dans, şiir gibi çeşitli sanat dalları da hayal gücünü güçlendiriyordu. ${ }^{121}$

Kilise tarafından çoğu kez dinsizlik suçlamasıyla karşı karşıya kalsa da, Veniamin'in, metafizik ve etiğe dair yazdığı eserlerinde, Aristotelesçi -skolastik- yaklaşımı tümüyle reddetmediği, hatta ampirik bilginin kaynağı olarak Aristoteles'e atıfta bulunduğu görülmektedir. ${ }^{122}$ Ruhban sınıfına mensup biri olarak Hristiyan inancından da uzaklaşmamaya çalışan Veniamin, eğitim konusunda, dinden yararlanmak gerektiğinin özellikle altını çiziyordu. ${ }^{123}$ Bununla birlikte fizik ve matematik öğretmeni olan Veniamin'in, kozmolojik olarak Kopernik'in ortaya attığı güneş merkezli evren kuramını savunuyor olması, ${ }^{124}$ Kilise' nin yer merkezli kuramına ters düştügü için tepki çekti. Onun bilimsel yaklaşımının temelini oluşturan, fiziksel ve metafiziksel fenomenleri yorumlamak için geliştirdiği $\pi \alpha v \tau \alpha \chi \eta \kappa i v \eta \eta \tau o v$ teorisi, ${ }^{125}$ hem bilim dünyasında hem de Kilise'de tartışmalara yol açtı. Ortodoks dünyasındaki inanç sistemini sarsacak bu tip öğretileri öğrencilerine aktarması ise Veniamin'in, Kilise bünyesindeki tutucu güçlerin hedefi haline gelmesine neden oldu. Önceki bölümlerde de değinildiği gibi, Veniamin'e yöneltilen suçlamalarda büyük payı olan Athanasios Parios ve onun önderliğinde gelişen Kollyvades Hareketi, Aydınlanma döneminde, en az aydınlanmacılar kadar etkin faaliyet yürüten bir diğer grup olarak karşımıza çıkmaktadır. Bu bağlamda, aynı çatı altında -Kilise bünyesinde- birbirine tezat oluşturan görüşlerin varlığg, ilginç bir noktayı teşkil etmektedir.

Aydınlanmacı görüşlerin Osmanlı Rum dünyasına ithal edilmesi, tutucu güçlerin girişimiyle birçok kez engellenmeye çalışılmış, yeni görüşlere sahip olan birçok din adamı ve öğretmen baskı altında tutulmuştu. Ancak Veniamin'in Ayvalık'ta bulunduğu süre içinde maruz kaldığı suçlamalardan temize çıkması, yine Kilise içinde, aydınlanmacı fikirlere sıcak bakan, aralarında Dorotheos Proios ile Efes Metropoliti Dionysios Kalliarhis (1803-1821)'in de bulunduğu bir grup ruhban üyesinin ve bazı Fenerli Rumların desteği ile gerçekleşti. Bu durum aslında Veniamin'in öğretilerinin, Osmanlı Rum aristokrasisi ve üst düzey ruhban sınıfı içinden bir kesimi etkilediğini ya da en azından kendisine taraftar bulduğunu göstermesi açısından önemlidir. Öyle ki, bu isimler, tutucu güçler tarafından "Veniaminciler/Veniamin yanlıları" olarak adlandırılmıştı. ${ }^{126}$

Bununla birlikte, sonraki süreçte Veniamin'in Ayvalık Akademisi'nden ayrılmasına yol açan gelişmelerde, kendisini Kilise karşısında destekleyen Efes Metropoliti Kalliarhis'in pay sahibi olması da, aydınlanmacılar -ya da aydınlanmacılara yakın duranlar- arasında bile fikir birliği olmadığını göstermektedir. Zira Kalliarhis'in müdahil olduğu, Veniamin'in Ayvalık'tan

\footnotetext{
${ }^{121}$ Aristeidis, a.g.e., s. 47-49.

${ }^{122}$ Argyropoulou, O Veniamin Lesvios: Oramatistis..., s. 79; Eleni Leontsini, "Morfes Filias sta Stoiheia İthikis tou Veniamin Lesviou: Arhaies, Neoteres kai Synhrones Prosengiseis", Agia Sion: Epistimoniki Epetiris Ieras Mitropoleos Mytilinis, Eresou kai Plomariou, Tomos 4, Mytilini, 2009, s. 147. Lesvoslu Veniamin'in Metafiziğin Unsurları adlı eseri için bkz. Veniamin Lesvios, Stoiheia tis Metafysikis, en Vienni tis Aoustrias, ek tis Typografias tou Ioannou Sneirer, 1820.

${ }_{123}$ Argyropoulou, O Veniamin Lesvios: Oramatistis ..., s. 122.

${ }^{124}$ A.g.e., s. 87.

${ }^{125}$ Pantahikiniton/pantachekineton, Türkçeye "her yerde hareket" şeklinde çevrilebileceği gibi, İngilizce kaynaklarda bu teoriye "her şeyin teorisi/theory of everything" şeklinde de rastlanmıştır. Söz konusu teoriyle ilgili detaylı bilgi için bkz. Argyropoulou, O Veniamin Lesvios: Oramatistis..., s. 91-93; E. Theodossiou, V. N. Manimanis, M. S. Dimitrijevic, "The Theory of Pantachekineton of Benjamin Lesvios", Journal Phlogiston The Journal of the Serbian Society for the History of Science, Vol. 18/19, March 2011, s. 7-32.

${ }^{126}$ Argyropoulou, O Veniamin Lesvios kai i Evropaiki Skepsi..., s. 76-77.
} 
ayrılmasına sebep olan 'görünürdeki' mesele, Yunan aydınlanmacıları arasında başından beri tartışmalara yol açan dil konusuydu. Ulusal farkındalığın gelişmeye başladığı bu döneme kadar eğitimde, ibadette ve günlük iletişimde Yunancanın farklı diyalektlerinin kullanılıyor olması, ulusun inşası sürecinde ortak bir dile duyulan ihtiyacı, aydınlanmacıların gündemine taşımıştı, çünkü dil, kültür aktarımının en önemli aracıydı ve ulusal kimliğin oluşturulması, en başta ortak bir dil yaratmakla mümkündü. Ancak mesele, hangi Yunancanın ortak dil olarak kabul edileceği noktasında düğümlenirken, taraflardan biri, Kilise'nin de kullandığ 1 Antik Yunancanın canlandırılarak ortak dile dönüştürülmesini savunuyor, diğeri ise bu dilin anlaşılmaz olduğu gerekçesiyle halk dilinin benimsenmesi gerektiğini öne sürüyordu. ${ }^{127}$ Veniamin'in dil meselesine yaklaşımı ise diğer birçok konuda olduğu gibi kendine özgüydü. Her şeyden önce, Yunancanın fonetik yapısının yazıya dökülmesini sağlayan yoğun noktalama işaretlerini, kendine özgü bir biçimde yorumlayarak farklı bir sistem geliştiren Veniamin, eserlerinde ağırlıklı olarak halk dilini kullanmış, ancak bilimsel terimlerin karşılıklarını da Antik Yunancadan tamamlamayı seçmişti. ${ }^{128} \mathrm{Bu}$ bağlamda, aslında, Adamantios Korais'in uzlaşmacı dil teorisine ${ }^{129}$ yakın bir tutum içinde olan, ancak ağırlıklı olarak basit bir konuşma dilini tercih eden Veniamin, görünüşte, bu yaklaşımından dolayı hem Ayvalık Akademisi'nin arkaik dil yanlısı müdürü Grigorios Sarafis'in hem de "öğrencilere doğru ve güzel bir dil ${ }^{130}$ ögretilmesi gerektiğini","131 öne süren Efes Metropoliti Kalliarhis'in hedefine oturmuştu.

Bu mesele, Veniamin'in Ayvalık Akademisi'nden ayrılmasının görünen nedeni olmakla birlikte, aydınlanmacılar arasındaki fikir ayrılıklarının aslında ne denli büyüyebildiğini gösteren bir örnektir. Ancak Veniamin'in okuldan ayrılmasının asıl gerekçesi, ideolojik tutumunun ve açık sözlülügünün Ayvalık'taki yerel güçler arasındaki çatışmayı şiddetlendirmesiydi. Kentte, Veniamin'in aydınlanmacı görüşlerini destekleyen Rum ticaret burjuvazisi ile tutucu güçlerle işbirliği halinde olan gelenekçi aristokratik sınıf arasındaki mücadele, cemaat içi hizipleşmenin ana eksenini oluştururken, cemaatin fonlarıyla ayakta durabilen bir okula bu hizipçiliğin yansımaması mümkün değildi. Bilhassa Veniamin'in, okuldan ayrılmadan bir-iki yıl kadar önce Ayvalık Rum cemaatine hitaben verdiği bir vaazda, idari gücün kötüye kullanılması, cemaat içi hizipçilik ve çatışmalar, sosyal bir sorun olarak alkolizm, argo ve küfür kullanımı, bilgisizlik ve hatta ruhban sınıfının cehaleti gibi konuları ele alarak cemaate ağır eleştiriler sunması, kaçınılmaz olarak sonunu hazırladı. ${ }^{132}$ Diğer bir ifadeyle Veniamin'in öğretileri, kendine özgü duruşu ve taviz vermeyen tutumu, Kilise içinde ve dişında tutucu/gelenekçi kesimi rahatsız ederken, aydınlanmacılar içinden bir grubun tepkisine de neden olmuştu. Ayvalık, Kalliarhis ve Veniamin üçgeninde yaşanan gelişmeler ve Veniamin' in Ayvalık Akademisi'nden ayrılması, bu duruma verilebilecek en yerinde örnektir.

Öte yandan Veniamin'in Batı Aydınlanmasından etkilenmesi, yalnızca bilimsel alanla sınırlı kalmadı; özgürlük, adalet, insan hakları, cumhuriyet, ulusçuluk gibi Fransız Devrimi menşeli siyasal ve sosyal ilkeler, onun etik ve siyasi düşüncelerinin temelini oluşturdu. ${ }^{133}$ Ayrica

\footnotetext{
${ }^{127}$ Millas, a.g.e., s. 47.

128 Argyropoulou, O Veniamin Lesvios kai i Evropaiki Skepsi..., s. 70; Argyropoulou, O Veniamin Lesvios: Oramatistis..., s. 44.

${ }^{129}$ Korais'in dil sorununa yaklaşımı ve önerisi için bkz. Millas, a.g.e., s. 169-171.

${ }^{130}$ Buradaki doğru ve güzel bir dilden kasıt, Antik Yunancadır.

${ }^{131}$ Efes Metropoliti Dionysios Kalliarhis'in, 1809 yılında Ayvalık Akademisi öğretmenleri Sarafis ve Veniamin'e hitaben kaleme aldığı mektup, dil konusunda Veniamin'e bir eleştiri niteliği taşıyordu. Mektubun yayınlanmış hali için bkz. Mihail D. Haviaras, "Symvoli eis tin Istorian tis Sholis ton Kydonion", Ksenofanis (Syngramma Periodikon tou Syllogou ton Mikrasiation Anatolis), Tomos Evdomos, en Athinais, 1910, s. 13-14.

${ }^{132} \mathrm{Bu}$ vaazın tarihi bulunmamakla birlikte, 1811 yılından önce kaleme alındığı bilgisi kaynaklarda aktarılmaktadır. Aristeidis, a.g.e., s. 59; Sotirakis, a.g.e., s. 10. Vaazın yaz1l1 metnini aktaran Aristeidis, a.g.e., s. 59-91.

${ }^{133}$ Argyropoulou, O Veniamin Lesvios: Oramatistis..., s. 41.
} 
Paris'te Korais çevresine girmesi de, onun Yunan Aydınlanmasında Korais'e yakın bir duruş sergilemesinde etkili oldu. Korais'in, yayınlanması için büyük katkı sunduğu, Yunan aydınlarını bir araya getiren ve amac1, Avrupa'daki ve Osmanlı egemenliğindeki Rumlara/Yunanlara aydınlanma düşüncesini aşılamak olan Logios Ermis'te ${ }^{134}$ çeşitli tarihlerde yazılar yazdı. Logios Ermis, Veniamin'in doğa bilimleri, felsefe ve eğitim ile ilgili düşüncelerinin daha geniş bir kitleye yayılmasında önemli rol oynadı.

Etik ve siyaset konusunda Aristotelesçi yaklaşımla Fransız aydınlanmasının liberal yönünü kaynaştıran Veniamin, ${ }^{135}$ verdiği derslerde ve yazdığ 1 eserlerde, ihtilalci fikirlere kaynaklık eden ilkeleri ve kavramları kullandı, bunları uygulama alanına geçirerek Osmanlı Rumlarının toplumsal ve siyasal dönüşümünde rol oynadı. Veniamin'in ulusçu yaklaşımının en tipik örneği, Antik Yunanca konuşmayı tercih etmese de, Antik Yunan kültürüne duyduğu hayranlıktır. Bütün yeni düşüncelerin kaynağının Antik Yunan'a dayandığını öne süren Veniamin, Antik Yunan kültürünü, yenilikçi felsefe ve bilimsel düşünceyle kaynaştırmaya çalıştı. Bu bağlamda romantik ulusçu bir çizgiye sahip olan Veniamin'in Antik Yunan'a duyduğu sayg1 ve hayranlığı, onun felsefesinde, teorilerinde, eserlerinde ve faaliyetlerinde görmek mümkündür. Her ne kadar Yunancanın kullanımı konusunda halk dilini tercih etse de, eserlerinde, yeni bilimsel terimlere Antik Yunancadan karşılık bulmaya çalışması, onun, Yunan dilinin zenginliğine inanmasından kaynaklanmaktayd1. ${ }^{136}$ Bükreş Akademisi’nde öğretmenlik yaptığ 1 sırada, Rumen ulusal bilincinin gelişmesi için felsefe öğretiminin Rumence yapılması konusuna olumsuz yaklaşan Veniamin, gerekçe olarak Rumen dilinin felsefe terimleri açısından Yunancaya göre daha fakir olduğunu göstermişti. ${ }^{137}$

Veniamin'in ulusçu tasarımlarını uygulama alanına geçirdiği ilk yer olan Ayvalık Akademisi ise başlı başına panhelenik bir misyona sahipti. Bu okulda Grigorios Sarafis ile birlikte Yunan ulusal bilincinin gelişmesine önderlik eden Lesvoslu Veniamin, bölge Rum halkına Helen kimliğini aşılamaya çalışıyordu. ${ }^{138} \mathrm{Bu}$ çerçevede Akademi, Rum toplumunda dini dayanışma olgusunun yerine, modern bir birliktelik olarak ulus fikrinin inşasına zemin hazırlarken, aydınlanmacı görüşlere başından beri karşı olan Kilise içindeki tutucu güçlere göre, ulusçuluk, Kilise'nin Ortodoks milleti üzerindeki bütünleştirici varlığını tehlikeye sokuyordu. Zaten henüz Ayvalık Akademisi açılmadan önce -1798 yılında- Osmanlı Devleti'ni Ortodoksluğu koruyan yüce bir varlık olarak niteleyen Patriki Didaskalia'nın ${ }^{139}$ yayımlanması, Kilise'nin aydınlanmacı ve ulusçu fikirler karşısında bundan sonra sergileyeceği tavrın habercisi niteliğindeydi. ${ }^{140}$ Dolayısıyla Kilise'nin Veniamin karşısındaki olumsuz tutumu, onun bilimsel yönüyle olduğu kadar ideolojik yönüyle de ilgiliydi.

Diğer yandan, Veniamin'in görüşleri, yalnızca Kilise'yi rahatsız etmiyor, aynı zamanda Osmanlı Devleti'nin varlığını ve bütünlüğünü de tehdit ediyordu. 1820 yılında dile getirdiği "Doğa, insanların tutkularına sinırlar koyar, Yunanlar hariç. Yunanlar, doğanın kurallarına ne önceden tabiilerdi, ne de şimdi."141 sözleri, Yunanların bağımsızlı taleplerinin bir

\footnotetext{
${ }^{134}$ Aleksandra Sfoini, “İ Glossa ton Efimeridon”, O Ellinikos Typos 1784 eos Simera, Istorikes kai Theoritikes Prosengiseis, (Ed. Loukia Droulia), Institouto Neoellinikon Erevnon Ethniko Idryma Erevnon, Athina, 2005, s. 101; Salahi R. Sonyel, Minorities and the Destruction of the Ottoman Empire, Turkish Historical Society Printing House (TTK Basımevi), Ankara, 1993, s. 164.

${ }_{135}$ Argyropoulou, O Veniamin Lesvios: Oramatistis..., s. 122.

${ }^{136}$ Argyropoulou, O Veniamin Lesvios kai i Evropaiki Skepsi..., s. 70.

${ }^{137}$ A.g.e., s. 92.

${ }^{138}$ Karamplias, a.g.e., s. 126, 128.

${ }^{139}$ Pederler Öğretisi.

${ }^{140}$ Clogg, Modern Yunanistan Tarihi, s. 26-27; Millas, a.g.e., s. 133-140.

${ }^{141}$ Dimaras, Neoellinikos Diafotismos, s. 128.
} 
yansıması niteliğindeydi. Osmanlı idaresi, ihtilalci ve ulusçu eğilimlere ve faaliyetlere karşı birtakım yaptırımlar uyguluyor olsa da, bunların hiçbirisi Veniamin'in şahsına yönelik gerçekleşmemişti. Kısa bir dönem Ayvalık Akademisi kapatılmış, ${ }^{142}$ Eflak ve Boğdan'da voyvodalar görevden alınmış ${ }^{143}$ veya ihtilal hazırlığ 1 içinde olduğu anlaşılan kişilere yönelik birtakım önlemlere başvurulmuştu. Bu tedbirlerin Veniamin'e yönelmemesinde, hiç şüphesiz onun, Osmanlı üst düzey bürokrasisinde yer almaması ve faaliyetlerini din adamı kimliği altında gizlice sürdürmesi etkili oldu. Böylece fazla dikkat çekmemiş ve Osmanlı idaresinin hedefi haline gelmemişti.

Ayvalık Akademisi'nde öğretmenlik yaptığı sırada, derslerinde kullanmak üzere oluş̧urduğu notlar, aynı zamanda Veniamin'in eserlerini oluşturmaktadır. Bu eserlerde, yetiştiği ortam ve yaşadığı olayların etkisi oldukça hissedilmektedir. Felsefe, fizik ve matematik olmak üzere üç başlık altında sınıflandırılabilecek olan Veniamin'in eserleri şunlardır: Stoiheia İthikis ${ }^{144}$ (Etiğin Unsurları), Stoiheia tis Metafysikis ${ }^{145}$ (Metafiziğin Unsurları), Fysiki ${ }^{146}$ (Fizik), Fysiki kai Meteorologia $^{147}$ (Fizik ve Meteoroloji), Astronomia ${ }^{148}$ (Astronomi), Stoiheia Arithmitikis ${ }^{149}$ (Aritmetiğin Unsurları), Geometrias Oiklidou Stoiheia ${ }^{150}$ (Öklid Geometrisinin Unsurları), Stoiheia Algebras ${ }^{151}$ (Cebirin Unsurlar1) ve Trigonometria ${ }^{152}$ (Trigonometri).

Veniamin, bu çalışmalarından dördünü, 1812-1817 yılları arasında İstanbul'da bulunduğu süre içinde basıma hazırladı. Bunlardan Aritmetiğin Unsurlarl, Öklid Geometrisinin Unsurları ve Metafiziğin Unsurlart 1818-1820 yılları arasında Viyana'da yayımlandı. ${ }^{153}$ Ancak basıma hazırladığı bir diğer eseri olan Etiğ̈in Unsurları, içeriğindeki Papizm karşıtı tutumdan dolayı Avusturya sansürüne uğradığı için yayımlanmadı. ${ }^{154}$ Ayrıca, Patrikhane'ye 1805 yılında verdiğ $i$ savunma (Apologia), ${ }^{155}$ çeşitli tarihlerde ve çeşitli mekânlarda verdiği nutuklar ${ }^{156}$ ve Logios Ermis'te yazdığı makaleler, Veniamin'in diğer eserleri arasında sayılmaktadır.

Volume 12

Issue 4

August

2020

\section{Sonuç}

Ruhban sınıfına mensup bir Yunan entelektüeli olan Lesvoslu Veniamin, Çağdaş Yunan Aydınlanması olarak adlandırılan sürecin en önemli temsilcilerinden biri kabul edilmektedir. Avrupa Aydınlanmasından etkilenen ve aydınlanmacı fikirlerini bir öğretmen olarak Osmanlı Rum toplumuna yaymaya çalışan Veniamin, yaşadığı dönemin gelenekçi çevresi içinde

\footnotetext{
${ }^{142}$ Karamplias, a.g.e., s. 141-142.

${ }^{143}$ Enver Ziya Karal, Osmanlı Tarihi (Nizam-ı Cedid ve Tanzimat Devirleri 1789-1856), V. Cilt, 9. B., TTK, Ankara, 2011, s. 50-52; Jelavich, a.g.e., s. 135.

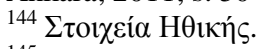

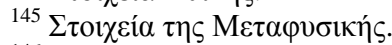

${ }^{146}$ Фvбıки́.

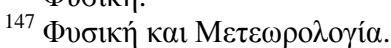

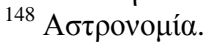

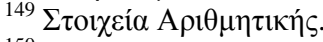

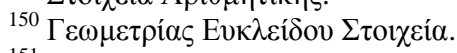

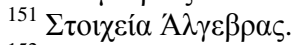

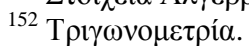

${ }^{153}$ Veniamin Lesvios, Stoiheia Arithmitikis, en Vienni tis Aoustrias, ek tis Typografias tou Ioannou Sneirer, 1818; Veniamin Lesvios, Geometrias Oiklidou Stoiheia, en Vienni tis Aoustrias, ek tis Typografias tou Ioannou Sneirer, 1820; Veniamin Lesvios, Stoiheia tis Metafysikis, en Vienni tis Aoustrias, ek tis Typografias tou Ioannou Sneirer, 1820.

${ }^{154}$ Argyropoulou, O Veniamin Lesvios kai i Evropaiki Skepsi..., s. 86-87; Sotirakis, a.g.e., s. 18.

${ }^{155} \mathrm{Bu}$ savunma metnini Sofoklis Oikonomos 1871 yılında yayımlamıştır. Sofoklis K. Oikonomos, Ta Sozomena Filologika Syngrammata Konstantinou Presvyterou kai Oikonomou tou eks Oikonomon, Tomos 1, Athinisi, 1871, s. 435-437.

${ }^{156}$ Ayvalık ve Bükreş’te verdiği nutukların tam metinleri için bkz. Aristeidis, a.g.e., s. 43-91.
}

\section{History Studies}


Sıradışı Bir Keșiş, Fizik Teorisyeni ve Öğretmen: Lesvoslu Veniamin

eleştirilere ve tepkilere maruz kalmıştır. Ancak bilim dünyasına yaptığı katkılarla bugün bile adından söz ettirmektedir.

Lesvoslu Veniamin'in yaşadığı dönem, eğitim gördüğü okullar, ders verdiği ve bulunduğu çevre, onun düşüncelerinin şekillenmesinde bir bütün olarak rol oynamıştır. Çalışma alanı olan matematik ve fen bilimlerini, felsefi düşüncenin temeli olarak gören Veniamin, Ayvalık'ta bulunduğu dönemden başlayarak Osmanlı egemenliğinde yaşayan Rum halkının eğitimi ve bilinçlenmesi için çaba göstermiştir. Aydınlanma felsefesinin getirdiği kültürel ve bilimsel tasarımları uygulama alanına sokmasıyla Rumlar arasında, hem Kilise'ye hem de Osmanlı Devleti'nin siyasal ve sosyal varlığına ters düşen yeni düşüncelerin yeşermesine yol açmıştır. Kilise'nin dogmatik ve statükocu anlayışına karşı deneysel bilimin yayılmasına öncülük etmiş, Osmanlı Devleti'ne karşı da Yunan aydınlanma hareketinin ihtilale dönüşmesine sebep olan özgürlük, adalet, insan hakları gibi Batı kökenli kavramları, soydaşlarının zihinlerine yerleştirme çabası içinde olmuştur.

Yunan ulusçuluğunun oluşumu evresinde, aydınlanmacı kavramları Rumlar üzerinden hayata geçirme isteği ve kendi kendine yetebilen bir Yunan ülkesi hayali, onu kaçınılmaz olarak Yunan ihtilalinde yer almaya sürüklemiştir. İhtilalin siyasi örgütlenmesinde önemli görevler üstlenen Veniamin, bu yönüyle Osmanlı Devleti’nin parçalanma sürecinde de rol oynamıştır.

Ortaya koyduğu eserlerinde, aydınlanma öğretilerini kendi bakış açısıyla harmanlayan Veniamin, bilim ve felsefe alanında kendine özgü bir tarz yaratmayı başarmış ve Yunan kültür dünyasının en özgün isimlerinden biri olarak tarihe geçmiştir.

\section{Kaynakça}

\section{Resmi Yayınlar}

Arheia tis Ellinikis Palingenesias mehri tis Engatastaseos tis Vasileias, Tomos 1, ek tou Typografeiou D. A. Mavrommati, en Athinais, 1857, (Epanekdosis ipo tis Vivliothikis tis Voulis, Athinai, 1971).

Arheia tis Ellinikis Palingenesias mehri tis Engatastaseos tis Vasileias, Tomos 2, Typois Dionysiou Koromila, en Athinais, 1862, (Epanekdosis ipo tis Vivliothikis tis Voulis ton Ellinon, Athinai, 1972).

Arheia tis Ellinikis Palingenesias (1821-1832): Ai Ethnikai Synelevseis, Tomos 3, Ekdosis Vivliothikis tis Voulis ton Ellinon, Athinai, 1971.

Kodiks ton Nomon, Fylladion A': Apanthisma ton Engklimatikon tis B' Ethniki Synelevseos ton Ellinon, ek tis en İdra Typografias, 1824.

\section{Kitaplar ve Makaleler}

AKSU, Ayşe, "Skolastik Eğitimden Helenizme Geçişte Bir Azınlık Okulu: İzmir Evangelike Rum Mektebi”, Kutadgubilig Felsefe-Bilim Araştırmaları, Say1 30, Haziran 2016.

ARGYROPOULOU, Roksani D., O Veniamin Lesvios kai i Evropaiki Skepsi tou Dekatou Ogdoou Aiona, Kentro Neoellinikon Erevnon Ethnikou İdrymatos Erevnon, Athina, 2003.

, O Veniamin Lesvios: Oramatistis kai Themeliotis tis Eleftherias ton Ellinon, Mikri Vivliothiki Didaskalon tou Genous, Athina, 2019. 
Çiğdem Kılıçoğlu Cihangir

ARGYROPOULOU, Roksani D. - Pashalis M. Kitromilidis, "O Diafotismos ston Horo tis Aiolidas", Mytilini kai Aivali (Kydonies), Mia Amfidromi Shesi sto Voreioanatoliko Aigaio, (Ed. P. M. Kitromilidis-P. Mihailaris), Institouto Neoellinikon Erevnon Ethnikou Idrymatos Erevnon, Athina, 2007.

ARISTEIDIS, G. A., Veniamin o Lesvios, Itoi Vios Aftou, Typois Proodou, Athinisi, 1880.

ARISTEIDIS-PAPPIS, G., Sympliroma eis tin kata to Etos 1880 Ekdotheisan ip'aftou Viografian Veniamin tou Lesviou, Typois Proodou, en Athinais, 1889.

CLOGG, Richard, Modern Yunanistan Tarihi, (Çev. Dilek Şendil), İletişim, İstanbul, 1997.

, "Two Accounts of the Academy of Ayvalık (Kydonies) in 1818-1819", $\dot{I}$ Kath'imas Anatoli: Studies in Ottoman Greek History, The Isis Press, İstanbul, 2004.

ÇíĞDEM, Ahmet, Aydınlanma Felsefesi, Ağaç Yayıncılık, İstanbul, 1993.

DAFNIS, Kostas, (Ed.), Arheion Ioannou Kapodistria, Tomos 7, Etaireia Kerkyraikon Spoudon, Kerkyra, 1986.

DIMARAS, K. Th., Ellinikos Romantismos, Ermis, Athina, 2009.

, Neoellinikos Diafotismos, 5. B., Ermis, Athina, 1989.

Ellinikos Filologikos Syllogos Konstantinoupoleos, Syngramma Periodikon, Tomos 12: 187778, Typois Voutyra kai Sas, en Konstantinoupolei, 1879.

EVANGELIDIS, Tryfon E., I Paideia epi Tourkokratias (Ellinika Sholeia apo tis Aloseos mehri Kapodistriou), Tomos 1-2, A. P. Halkiopoulou, en Athinais, 1936.

FILIMON, Ioannis, Dokimion Istorikon peri tis Ellinikis Epanastaseos, Tomos 1-3, Typois P. Soutsa kai A. Ktena, Athinai, 1859-1860.

Dokimion Istorikon peri tis Filikis Etaireias, ek tis Typografias Th. Kontaksi kai N. Loulaki, en Nafplia, 1834.

GREENE, Molly, Osmanl Devleti ve Rumlar 1453-1768, (Çev. Zeynep Rona), Kitap Yayınevi, İstanbul, 2018.

HAKAN, Ayhan, "Dünyada ve Türkiye'de Akademilerin Tarihçesi ve Bugünkü Durumu", Ankara Üniversitesi Eğitim Bilimleri Fakültesi Dergisi, C. 15, S. 2, 1982.

HAVIARAS, Mihail D., "Symvoli eis tin Istorian tis Sholis ton Kydonion", Ksenofanis (Syngramma Periodikon tou Syllogou ton Mikrasiation Anatolis), Tomos Evdomos, en Athinais, 1910.

HORKHEIMER, Max- Theodor W. Adorno, Aydınlanmanın Diyalektiği, Felsefi Fragmanlar, (Çev. Nihat Ülner, Elif Öztarhan Karadoğan), Kabalcı Yayıncılık, İstanbul, 2014.

JELAVICH, Barbara, Balkan Tarihi 18. ve 19. Yüzyıllar, (Çev. İhsan Durdu, Gülçin Tunalı, Haşim Koç), Küre Yayınları, İstanbul, 2006.

JUSDANIS, Gregory, Gecikmiş Modernlik ve Estetik Kültür: Milli Edebiyatın İcat Edilişi, (Çev. Tuncay Birkan), Metis Yay., İstanbul, 1998.

KARAL, Enver Ziya, Osmanlı Tarihi (Nizam-ı Cedid ve Tanzimat Devirleri 1789-1856), V. Cilt, 9. B., TTK, Ankara, 2011. 
Sıradışı Bir Keşiş, Fizik Teorisyeni ve Öğretmen: Lesvoslu Veniamin

KARAMPLIAS, Ioannis N., Ístoria ton Kydonion, Typografeion Ger. S. Hristou \& Yios, Athinai, 1949.

KELAĞA AHMET, İbrahim, "Çağdaş Yunan Aydınlanma Hareketinin Coğrafyası, Ortaya Çıkış Süreci ve Eğitim Alanındaki Etkileri”, Batı Kültür ve Edebiyatlarında Aydınlanma, (Yay. Haz. Battal Arvasi, Çağrı Eroğlu, Ebru Balamir, İlhan Karasubaşı), Ankara Üniversitesi Yay., Ankara, 2014.

Yunanca-Türkçe Arkaik Sözler ve Eylemsiler Sözlüğ̈̈, İthaki Yay., İstanbul, 2016.

KIMINAS, Demetrius, The Ecumenical Patriarchate: A History of Its Metropolitanates with Annotated Hierarch Catalogs, The Borgo Press, USA, 2009.

KITROMILIDIS, Pashalis M., "Aydınlanma ve Yunan Kültürel Geleneği”, Tarih Eğitimi ve Tarihte Öteki Sorunu, (2. Uluslararası Tarih Kongresi-Tebliğler), 2. B., Tarih Vakfı Yurt Yayınları, İstanbul, 2017.

, Neoellinikos Diafotismos: Oi Politikes kai Koinonikes İdees, Morfotiko İdryma Ethnikis Trapezis, Athina, 2009.

KITROMILIDIS, Paschalis M.- Alexis Alexandris, "Ethnic Survival, Nationalism and Forced Migration: The Historical Demography of the Greek Community of Asia Minor at the Close of the Ottoman Era", Deltio Kentrou Mikrasiatikon Spoudon, Tomos Pemptos, Athina, 1984.

KURMUŞ, Orhan, Emperyalizmin Türkiye’ye Girişi, 2. B. Yordam Kitap, İstanbul, 2012.

KÜTÜKOĞLU, Mübahat S., "Yunan İsyanı Sirasında Anadolu ve Adalar Rumlarının Tutumları ve Sonuçları", Üçüncü Askeri Tarih Semineri: Tarih Boyunca Türk-Yunan Illişkileri (20 Temmuz 1974'e Kadar), Genelkurmay ATASE Yay., Ankara, 1986.

LEONTSINI, Eleni, "Morfes Filias sta Stoiheia İthikis tou Veniamin Lesviou: Arhaies, Neoteres kai Synhrones Prosengiseis", Agia Sion: Epistimoniki Epetiris Ieras Mitropoleos Mytilinis, Eresou kai Plomariou, Tomos 4, Mytilini, 2009.

LESVIOS, Veniamin, Geometrias Oiklidou Stoiheia, en Vienni tis Aoustrias, ek tis Typografias tou Ioannou Sneirer, 1820.

, Stoiheia Arithmitikis, en Vienni tis Aoustrias, ek tis Typografias tou Ioannou Sneirer, 1818.

, Stoiheia tis Metafysikis, en Vienni tis Aoustrias, ek tis Typografias tou Ioannou Sneirer, 1820.

MANDILAS, Kostas P., O Theofilos Kairis kai o Neoellinikos Diafotismos, Ekdoseis Anoihti Poli, Athina, 2002.

MEKSAS, Valerios G., Oi Filikoi: Katalogos ton Melon tis Filikis Etaireias ek tou Arheiou Sekeri, Athinai, 1937.

METALLINOS, Georgios D., “İ Dynamiki tou Diafotismou sti Drasi tou Kollyvadon”, $O$ Eranistis, 21, 1997.

MİLLAS, Herkül, Yunan Ulusunun Doğuşu, 2. B., İletişim Yay., İstanbul, 1999.

OIKONOMOS, Sofoklis K., Ta Sozomena Filologika Syngrammata Konstantinou Presvyterou kai Oikonomou tou eks Oikonomon, Tomos 1, Athinisi, 1871. 
Çiğdem Kılıçoğlu Cihangir

ORAKÇI, Meryem, “Karamanlıca Muhacir Sedası Gazetesine Göre Yunanistan'da Mübadelenin İlk Yılları ve Türkçe Konuşan Ortodoksların Yaşadığı Sorunlar", Ankara Üniversitesi Türk İnklap Tarihi Enstitüsü Atatürk Yolu Dergisi, Say1: 65, Güz 2019.

ROUDOMETOF, Victor, Nationalism, Globalization and Orthodoxy: The Social Origins of Ethnic Conflict in the Balkans, Greenwood Press, Westport, Connecticut, 2001.

SAKKARIS, Georgios, Istoria ton Kydonion, Syllogos pros Diadosin Ofelimon Vivlion, Athinai, 1920, (Anatyposi 2005).

SANDYS, John Edwin, A History of Classical Scholarship: The Eighteenth Century in Germany and the Nineteenth Century in Europe and the United States of America, Vol. 3, Cambridge University Press, 2010.

SFOINI, Aleksandra, "I Glossa ton Efimeridon”, O Ellinikos Typos 1784 eos Simera, Istorikes kai Theoritikes Prosengiseis, (Ed. Loukia Droulia), Institouto Neoellinikon Erevnon Ethniko Idryma Erevnon, Athina, 2005.

SOLOMONIDIS, Hristos Sokratis, İ Paideia sti Smyrni, Athina, 1962.

SONYEL, Salahi R., Minorities and the Destruction of the Ottoman Empire, Turkish Historical Society Printing House (TTK Basımevi), Ankara, 1993.

SOTIRAKIS, Nikos D., Veniamin Lesvios - Viografia, Mytilini, 1939.

SOUTZOS, Dimitris Skarlatos, Ellines İgemones Vlahias kai Moldavias, Athina, 1972.

STRATIS, Dimitrios, "Sheseis Agiou Orous kai Kydonion", Mytilini kai Aivali (Kydonies), Mia Amfidromi Shesi sto Voreioanatoliko Aigaio, (Ed. P. M. Kitromilidis-P. Mihailaris), Institouto Neoellinikon Erevnon Ethnikou Idrymatos Erevnon, Athina, 2007.

SVORONOS, Nikos, Çağdaş Helen Tarihine Bakış, (Çev. Panayot Abacı), Belge Yay., İstanbul, 1988.

THEODOSSIOU, E.- V. N. Manimanis- M. S. Dimitrijevic, "The Theory of Pantachekineton of Benjamin Lesvios", Journal Phlogiston The Journal of the Serbian Society for the History of Science, Vol. 18/19, March 2011.

UBICINI, Abdolonyme, Letters on Turkey: An Account of the Religious, Political, Social and Commercial Condition of the Ottoman Empire, Part II, The Raiahs, including the Greeks, Armenians, Latins, Israelites, London, 1856.

VAIANNI, Maria N., Mikrasiatikos Ellinismos kai Filekpaideftiki Etaireia 1836-1900, Ekdoseis Enoseos Smyrnaion, Athina, 2003.

VALETAS, Giorgos, "Istoria tis Akadimias ton Kydonion", Mikrasiatika Hronika, Tomos 4, 1948.

, Veniamika: Ta Mikra Keimena tou Veniamin Lesviou kai oi Viografikes Piges tou, Ekdoseis Etaireias Aiolikon Meleton, Mytilini, 1982.

YILDIRIM, Mustafa, "17. Yüzyılda Avrupa'da Kurulan Bilim Akademileri ve Bilimsel Gelişmelerdeki Rolleri”, ÇKÜ Sosyal Bilimler Enstitüsü Dergisi, Cilt: 10, Özel Sayı, Aralık 2019.

YORULMAZ, Ahmet, Ayvalık’ı Gezerken, 4. B., Geylan Kitabevi, 1994. 